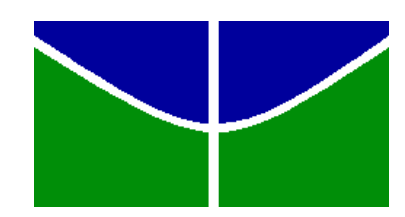

UNIVERSIDADE DE BRASÍLIA - UnB

INSTITUTO DE CIÊNCIAS HUMANAS - IH

DEPARTAMENTO DE SERVIÇO SOCIAL - SER

\title{
MEDIDAS ALTERNATIVAS À PRISÃO SIGNIFICADO E ALCANCE SOCIOEDUCATIVO
}

Izabel Fernandes Gomes

Brasília, 2009. 


\title{
MEDIDAS ALTERNATIVAS À PRISÃO \\ SIGNIFICADO E ALCANCE SOCIOEDUCATIVO
}

\author{
Izabel Fernandes Gomes
}

\begin{abstract}
Trabalho de Conclusão de Curso (TCC) apresentado ao Departamento de Serviço Social da Universidade de Brasília como requisito parcial para obtenção do título de Assistente Social sob orientação da $\operatorname{Prof}^{\mathrm{a}} \operatorname{Dr}^{\mathrm{a}}$ Potyara A. P. Pereira.
\end{abstract}

Brasília, 2009. 


\section{Termo de Aprovação}

Trabalho defendido e aprovado pela banca examinadora abaixo assinada:

Prof $^{a} \operatorname{Dr}^{\mathrm{a}}$ Potyara Amazoneida Pereira Pereira

Orientadora

Universidade de Brasília - UnB

\section{Prof $^{a}$ Dr $^{\mathrm{a}}$ Rosa Helena Stein \\ Examinadora \\ Universidade de Brasília - UnB}

Joselito da Silva Pacheco

Examinador

Universidade de Brasília - UnB 
Dedico este trabalho primeiramente a Deus; aos meus pais, pelo incentivo e apoio; e aos meus irmãos por estarem comigo em todos os momentos. 


\section{Agradecimentos}

Este Trabalho de Conclusão de Curso é fruto de uma longa jornada, que não se iniciou na Universidade de Brasília. Por isso, começo agradecendo a todos que de alguma maneira passaram pela minha vida e contribuíram com quem sou hoje.

Agradeço, em especial, a algumas pessoas que tiveram contribuição direta na elaboração deste trabalho:

À minha amada mãe, Ednévea, por não ter medido carinho e esforço para que eu chegasse a esta etapa da minha vida.

Ao meu querido pai, Luiz, por sempre me apoiar e estar do meu lado.

Aos meus irmãos, Juliano, Guilherme e Raquel, por saber que posso "contar" com vocês!

Às minhas avós, Antônia e Ivanice, por transmitirem experiências e histórias que jamais serão esquecidas.

A todos os meus amigos, pela convivência e aprendizado que me proporcionam.

Ao meu namorado, Henrique, pela compreensão, carinho e companheirismo.

À equipe SeMA-PJBZ, incluindo os autores de delitos, por terem despertado em mim o interesse pelo compromisso social.

À professora Potyara Pereira, pelas contribuições teóricas e pela paciência que teve com as minhas falhas, sendo sempre muito cuidadosa e competente para guiar os estudos.

À professora Rosa Stein e ao pesquisador Joselito Pacheco por tão gentilmente terem aceitado o convite para compor a banca examinadora deste TCC. 
"Para se fazer grandes coisas não se deve estar acima dos homens, mas junto deles". 


\section{Resumo}

Este Trabalho de Conclusão de Curso tem como objeto de estudo o significado e alcance socioeducativo da medida alternativa à prisão. Seu lócus de análise foi a Região Administrativa de Brazlândia , Distrito Federal. Por meio de pesquisa em fontes secundárias e primárias, foi realizada uma abordagem teórica, histórica e empírica sobre a temática. A pesquisa empírica valeu-se da técnica de entrevista que foi instrumentalizada por questionários respondidos pelos atores sociais que atuam na aplicação e no acompanhamento da medida alternativa (autor do fato, instituições parceiras e Ministério Público do Distrito Federal e Territórios). A medida alternativa à prisão é um instituto que permite a não privação da liberdade do indivíduo que está sendo processado por algum delito que cometeu. Porém, para não ter aplicação de pena de prisão, o Ministério Público faz acordo com o autor do fato para que este cumpra medida alternativa, normalmente caracterizada como prestação de serviço ou pecuniária. O presente estudo tem por finalidade verificar se o cumprimento da medida alternativa à prisão tem função socioeducativa, permitindo que o autor do fato não tenha a sua liberdade cerceada e possa ser útil à sociedade à qual pertence.

Palavras-Chave: Medida Alternativa à Prisão; Prestação de Serviço e Prestação Pecuniária; Função Socioeducativa. 


\begin{abstract}
This Final Paper has as objective to study the meaning and the social-educational reach of the alternative method to the prison. Its' analysis locus was the Administrative Area of Brazlândia of Distrito Federal. To achieve this objective it was used the method of research in secondary and primary sources, a theoretical, historical and empiric approach on the theme. The empiric research was realized by the technique of interview that had as an instrumentation questionnaires answered by the social actors that act in the application and in the attendance of the alternative method (author of the fact, partners institutions and the Ministério Público do Distrito Federal e Territórios). The alternative method to the prison is an institute that allows the non privation of the individual's freedom that is being processed by some crime that had committed. However, not to have the application of imprisonment, the Ministério Público fix an agreement with the author of the fact for they to accomplish the alternative method, usually characterized as lending of service or financial. The present study has as purpose to verify whether the execution of the alternative method to the prison has the social-educational function, allowing the author of the fact not to have his freedom reduced and it can be useful to the society to which belongs.
\end{abstract}

Key Words: Alternative Method to the Prison; Installment of Service and Financial; Socialeducational Function. 


\section{Lista de Abreviaturas}

1. CeMA - Central de Medidas Alternativas

2. $\mathrm{CF}-$ Constituição Federal

3. DF - Distrito Federal

4. ISMA - Informações do Setor de Medidas Alternativas

5. MPDFT - Ministério Público do Distrito Federal e Territórios

6. $\quad$ ONU - Organização das Nações Unidas

7. p. - Página

8. PJBZ - Promotoria de Justiça de Brazlândia

9. REEM - Relatório de Evolução na Execução da Medida

10. RIS - Relatório de investigação Social

11. SeMA - Setor de Medidas Alternativas

12. SISDEMA - Setor de Investigação Social para Delitos de Meio Ambiente, Ordem Urbanística e Patrimônio Público

13. SISDEV - Setor de Investigação Social para Delitos de Entorpecentes, Violência Doméstica e Maus-Tratos

14. TCC - Trabalho de Conclusão de Curso 


\section{Sumário}

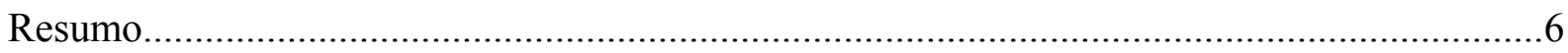

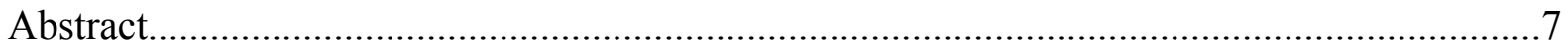

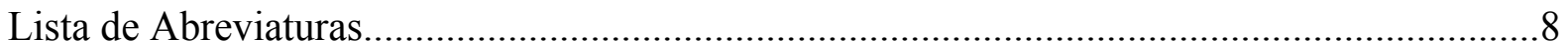

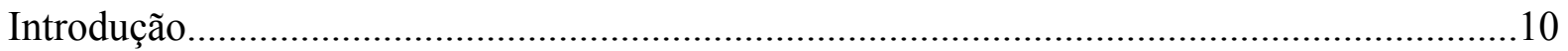

CAPÍTULO I - MEDIDAS ALTERNATIVAS À PRISÃO................................................13

1.1 Histórico das Prisões e Conceito de Medida Alternativa........................................14

1.2 Modalidades e Tipos das Medidas Alternativas...................................................20

1.3 Central de Medidas Alternativas do MPDFT - SeMA/PJBZ ................................23

1.4 Abordagem Teórico- Metodológica.....................................................................26

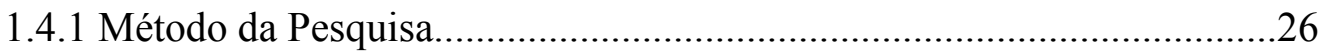

1.4.2 Critérios para Seleção dos Participantes da Pesquisa............................27

1.4.3 Técnicas e Instrumentos para Coleta de Dados...................................27

CAPÍTULO II - REFERENCIAL TEÓRICO...............................................................29

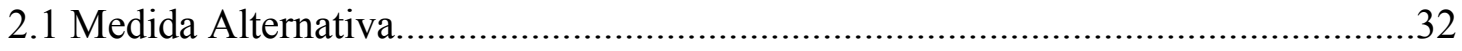

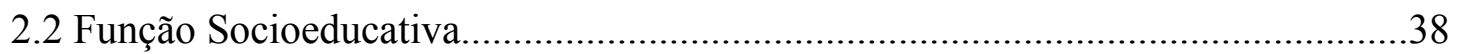

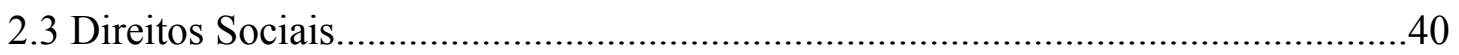

CAPÍTULO III - APRESENTAÇÃO E ANÁLISE DOS RESULTADOS.........................42

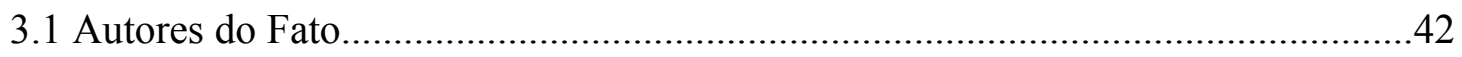

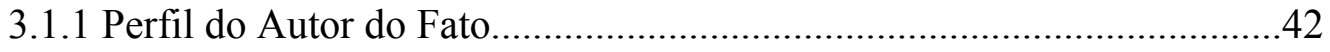

3.1.2 Avaliação do Autor do Fato em Relação à Medida Alternativa..............43

3.1.3 Avaliação do Autor do Fato em Relação à Instituição............................44

3.1.4 Avaliação do Autor do Fato em Relação ao Sistema de Justiça...............46

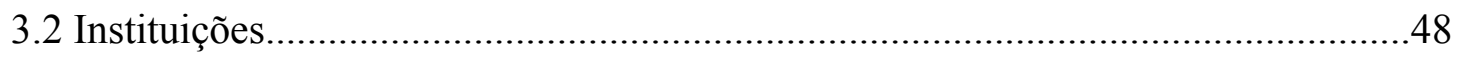

3.3 Servidor do SeMA/PJBZ e Promotor de Justiça......................................................49

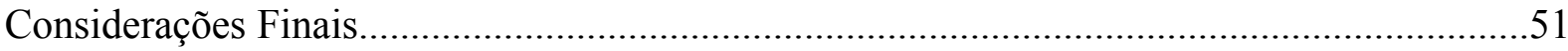

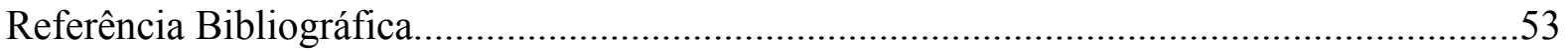

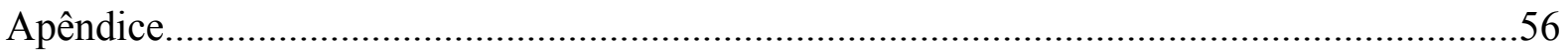

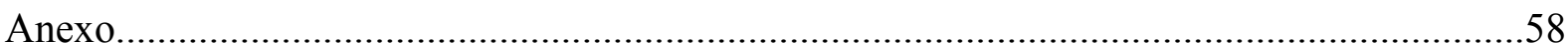




\section{Introdução}

O presente Trabalho de Conclusão de Curso (TCC) é requisito obrigatório para a formação acadêmica do curso de Serviço Social da Universidade de Brasília e tem por finalidade analisar o significado e alcance socioeducativo da medida alternativa à prisão no âmbito da Região Administrativa de Brazlândia do Distrito Federal.

Seu objeto de interesse é o significado e contribuição socioeducativos da medida alternativa para o autor de fato delituoso, com base na experiência e percepção desse autor sobre: o cumprimento e a opção pela medida; a participação da instituição, onde cumpriu a medida, no processo socioeducativo; e o acerto (ou não) do órgão ministerial ao propor-lhe a medida.

A intenção de descobrir o significado e a contribuição social da medida alternativa conduziu à seguinte indagação: A execução da medida alternativa à prisão contribui para a socioeducação do autor do fato? O que ela representa para a instituição onde é realizada e para a justiça?

A hipótese formulada com base no questionamento acima foi: a execução da medida alternativa tem importante função socioeducativa pelo fato de proporcionar ao autor do delito a possibilidade de não privá-lo do convívio social e de torná-lo útil à sociedade no mesmo momento em que está cumprindo a medida.

O objetivo da investigação foi dividido em geral e específico, a saber:

Geral: verificar se a atuação do Ministério Público e da instituição em que se dá o cumprimento da medida alternativa contribui para garantir efeito socioeducativo ao autor do delito e se há efetiva integração entre a aplicação da medida e os serviços e políticas sociais disponíveis.

Específicos:

- traçar o perfil dos autores do fato que cumpriram medida alternativa na Região Administrativa de Brazlândia (faixa etária, escolaridade, quantidade de filhos, trabalho);

- averiguar a opinião desses autores sobre: a medida alternativa; os efeitos socioeducativos desta; o papel da instituição onde cumpriram a medida; e o significado da sua proposição pelo órgão ministerial;

- analisar duas instituições de Brazlândia, sendo uma pública e outra privada, para avaliar suas atuações perante os autores do fato; 
- identificar a concepção da servidora do SeMA/PJBZ sobre medida alternativa, e do Promotor de Justiça de Brazlândia que trabalham diretamente com essa temática

O interesse despertado por esse tema se deu pelos seguintes motivos:

a) experiência vivenciada por esta estudante durante seu Estágio Supervisionado no Setor de Medidas Alternativas da Promotoria de Justiça de Brazlândia, que é um Setor integrante do organograma do MPDFT;

b) interesse desta aluna por estudos sobre ramos do Direito Penal relacionados ao Serviço Social;

c) vontade de contribuir cientificamente para o avanço do instituto da medida alternativa.

O estudo foi realizado no âmbito do Setor de Medidas Alternativas da Promotoria de Justiça de Brazlândia, que é uma unidade da Central de Medidas Alternativas do Ministério Público do Distrito Federal e Territórios. Foram utilizados os conceitos de função socioeducativa, medida alternativa e direitos sociais como categorias centrais da discussão sobre o tema.

Função socioeducativa significa preparar o indivíduo para o convívio social, desenvolvendo seu potencial para não ter sua liberdade cerceada (COSTA, 2006, p. 449). Vários são os atores sociais que auxiliam ou deveriam auxiliar na efetivação dessa função no caso das medidas alternativas: a justiça, as instituições públicas e privadas, a família e a comunidade. Neste estudo foram analisadas as contribuições da justiça e das instituições que participam diretamente do processo de aplicação da medida alternativa.

Medida alternativa à prisão, não é considerada pena, mas acordo entre o autor do fato e o Estado (representado pelo Juiz) para que não se instaure ou se interrompa o processo judicial. São casos de medida alternativa: a transação penal e a suspensão condicional do processo (BARROSO, 2003, p. 84).

Direitos sociais são entendidos como direitos à prestações sociais garantidas pelo Estado por meio de políticas públicas tais como: saúde, educação, trabalho, habitação, assistência social entre outras (PAULO e ALENXANDRINO, 2007, p. 97).

Em suma, o principal intento desta pesquisa foi verificar as percepções dos autores de delitos, que cumpriram medida alternativa, quanto à importância desse cumprimento para si, para a instituição onde cumpriram a medida e para a justiça, levando em consideração que a finalidade da medida alternativa é educação e socialização. Ou melhor, o objetivo foi conhecer, por meio de informações prestadas por pessoas que cumpriram integralmente 
medida alternativa, o significado e a contribuição social dessa medida para os atores envolvidos (autor do fato, instituição e justiça).

Para tanto, basicamente foi realizado: estudo sobre as abordagens teóricas das medidas alternativas; análise sobre o processo de operacionalização e organização da execução dessas medidas; e avaliação da sua função socioeducativa.

A metodologia foi construída tendo por eixo analítico as três categorias já citadas, que servem de parâmetro conceitual para a investigação em suas diversas fases. No entanto, convém salientar que houve dificuldades para a coleta de dados em fontes secundárias, pois há poucas referências bibliográficas sobre a temática estudada.

O TCC está dividido em três capítulos.

O primeiro diz respeito ao histórico das prisões, conceito de medida alternativa, e à análise da ineficácia do modelo prisional brasileiro que deu ensejo ao surgimento de mecanismos alternativos à prisão capazes de punir os transgressores da lei sem que haja privação da liberdade. Neste capítulo são apresentados: conceito, histórico, tipos e modalidades das medidas alternativas, assim como a Central de Medidas Alternativas do Ministério Público do Distrito Federal e Territórios que trabalha diretamente com este instituto. Este capítulo contempla também a abordagem teórico-metodológica construída para a análise do objeto de estudo, o método e os tipos de fontes utilizados na pesquisa.

O segundo capítulo trata do referencial teórico do trabalho, discutindo as categorias de análise: medida alternativa, função socioeducativa e direitos sociais.

Por fim, no terceiro e último capítulo apresenta-se os resultados da pesquisa empírica realizada no Setor de Medidas Alternativa da Promotoria de Justiça de Brazlândia. Este capítulo é importante para se entender a operacionalização da medida alternativa e para se verificar a comprovação da hipótese levantada durante a pesquisa.

O presente trabalho se encerra com as Considerações Finais, nas quais são apresentados pontos que merecem destaques conclusivos, seguidos de estimulação à continuidade dos estudos e das reflexões sobre o significado e o alcance das medidas alternativas à prisão. 


\section{Capitulo I}

\section{Medidas Alternativas à Prisão}

A necessidade de pesquisar a função socioeducativa da medida alternativa surgiu tendo em vista a contribuição que esse instituto pode trazer para a sociedade como um todo. Contribuição esta que pode ser evidenciada com a obrigação que a medida impõe a outras esferas e instituições de terem responsabilidade com a integração social dos autores de delito. Essa obrigação coloca a sociedade mais próxima desses autores, uma vez que a medida alternativa a ser cumprida serve para beneficiar e estar mais próxima da sociedade.

Além disso, a função socioeducativa de medida alternativa é uma temática relevante, pois a pesquisa de seus limites e possibilidades pode contribuir para a melhor utilização desse instituto como instrumento eficaz para: garantir o convívio social do autor do fato e aperfeiçoar a função punitiva da justiça, que nem sempre precisa restringir a liberdade desse autor. No caso particular da Central de Medidas Alternativas do MPDFT, pesquisas como esta podem fornecer elementos de avaliação do trabalho realizado e de mudanças que poderão ser implementadas para se atingir o objetivo que as medidas socioeducativas perseguem. E dentre essas mudanças, a inserção do profissional de Serviço Social para atuar no processo socioeducativo é uma das mais urgentes.

Com efeito, outras experiências brasileiras já colocam esse profissional como importante para garantir não só a efetividade da medida, mas também o acesso aos direitos e às políticas sociais. É nessa perspectiva que reside a importância do estudo da medida alternativa para esta aluna de Serviço Social, pois este instituto está inserido numa prática sócio-jurídica que tem por finalidade garantir ao autor do fato permanência e utilidade na sociedade, com direitos garantidos.

A medida alternativa surgiu como uma possibilidade de diminuir os problemas oriundos do sistema penitenciário brasileiro e melhor atender os direitos e os interesses da população. Para Dotti (1998, p. 31), as medidas alternativas à prisão "buscam emprestar maior eficácia e significação ao Direito Penal".

Diante desse fato é necessário iniciar a discussão apresentando o histórico e as características das prisões para melhor entender as soluções alternativas às penas privativas de liberdade. 
Como já foi informado, o conteúdo deste primeiro capítulo se destina a apresentação do histórico e do conceito das medidas alternativas, tendo como ponto de partida apresentação do histórico e da função da prisão. Serão também apresentados os tipos e modalidades das medidas alternativas e a Central de Medidas Alternativas do MPDFT, que trabalha diretamente com esse instituto.

\subsection{Histórico das Prisões e Conceito de Medida Alternativa}

A pena de prisão é uma forma de privação da liberdade do individuo e limitação do seu convívio social. Essa pena é normalmente aplicada pelo fato de o indivíduo ter sido condenado, de acordo com a lei, por algum crime que cometeu.

Na Antiguidade (4.000 a.C. até o Século V), a privação da liberdade serviu para preservar fisicamente os réus no momento do julgamento ou da execução. Segundo Bitencourt, "a prisão era uma espécie de ante-sala de suplícios" (2004, p. 4), pois servia para aguardar a pena que seria aplicada, dentre elas a de morte, que, na época, era recorrentemente utilizada. Outro aspecto, referente às prisões da época eram as suas condições físicas degradantes, conforme destaca Bitencourt:

\footnotetext{
Os lugares onde se mantinham os acusados até a celebração do julgamento eram bem diversos, já que naquela época não existia ainda uma arquitetura penitenciária própria. Os piores lugares eram empregados como prisões: utilizavam-se horrendos calabouços, aposentos frequentemente em ruínas ou insalubres de castelos, torres, conventos abandonados, palácios e outros edifícios (idem, 2004, p.7).
}

Com base nessas informações, é possível perceber que, na Antiguidade, não havia preocupação com os direitos humanos e com as condições materiais dos cárceres. Dotti (1998, p. 32) confirma que "a prisão se infligia no interesse de assegurar a execução de penas corporais, especialmente a de morte, além de servir para a colheita de prova mediante tortura".

Na Idade Média (Século V ao Século XV), a lei penal tinha o principal objetivo de gerar medo. A prisão ainda era utilizada para o preso aguardar a aplicação de sua pena. A maioria das pessoas que eram privadas de liberdade contrariava o Estado (tornando-se inimigos do poder) ou contrariava a Igreja, sendo a prisão neste caso é uma forma de 
penitência e meditação (BITENCOURT, 2004, p. 9-10). As penas aplicadas, também nessa época, estavam fortemente relacionadas a castigos corporais.

Com efeito, a prisão era usualmente utilizada como instrumento espiritual do castigo, pois o pensamento da igreja católica fundamentava-se no fato de que, com o sofrimento e a solidão, o homem era capaz de se salvar dos pecados. "A igreja via no delito a expressão do pecado e para dirimir a culpa o infrator deveria sujeitar-se à penitência que poderia aproximálo de Deus". (DOTTI, idem, p. 33).

Cesare Beccaria escreveu sua obra Dos Delitos e Das Penas com o objetivo de se contrapor à tradição jurídica da época. Visando justificar a utilização da prisão como um recurso a serviço da justiça, o referido autor (2003, p. 28) argumenta:

[...] o sistema atual da jurisprudência criminal apresenta aos nossos espíritos a idéia da força e do poder, em vez da justiça; é que se atiram, na mesma masmorra, sem distinção alguma, o inocente suspeito e o criminoso convicto; é que a prisão, entre nós, é antes de tudo um suplício e não um meio de deter um acusado; é que, enfim, as forças que estão, externamente em defesa do trono e dos direitos da nação estão separadas daquelas que mantêm as leis no interior, quando deveriam estar intimamente ligadas.

Dessa análise, é possível constatar a ideologia dominante, à época, no que concerne à prisão; e, ao mesmo tempo, informar que Beccaria foi considerado um paladino pioneiro das causas contra a prática de torturas, penas de morte, prisões desumanas, banimentos, acusações secretas, dentre outras penas injustas e vingativas.

Na Idade Moderna (Século XVI e XVII), a pobreza se alastrou pela Europa e os pobres começaram a pedir esmolas, roubar e cometer homicídios. Diante da magnitude dessas ocorrências, a pena de morte já não era mais um meio eficiente, pois seria aplicada a grande parcela da população, que era considerada delinqüente. Em vista disso, tiveram início as prisões organizadas com a finalidade de corrigir os apenados privados de liberdade. Nessas prisões eram recolhidos os vagabundos, ociosos, ladrões e autores de pequenos delitos (BITENCOURT, idem, p. 18).

Nos presídios, os delinqüentes eram forçados a trabalhar. Com esta medida, pretendia-se desestimular que outras pessoas seguissem a vida na ociosidade. Mas, apesar da repressão nas prisões, os atos delituosos não diminuíram, demonstrando que, com violência, não se debela a violência. Dotti (1998, p. 37) apresenta uma justificativa para o aumento da delinqüência: "O desterro das cidades e a inflição das penas corporais haviam contribuído 
para o êxito de uma delinqüência extremamente perigosa e que se expandia com grande rapidez, pois as guerras e as revoluções desacreditavam os velhos poderes”.

Como exemplo das cadeias desse período, é digno de nota o panóptico, criado por Jeremy Bentham ${ }^{1}$, que tinha uma construção arquitetônica circular, para os apenados pensarem que estavam sendo vigiados constantemente. A criação de Bentham "evolui ao ponto de oferecer a direção do estabelecimento que permitia vigilância absoluta e completa disciplina" (DOTTI, 1998, p. 38).

O surgimento das workhouses na Inglaterra é outro exemplo das prisões desse período, sendo destinadas aos pobres sem trabalho e que precisavam da ajuda do Estado. Traduzida para o português como "casa dos pobres", esta foi originada com o objetivo de conter a vagabundagem e funcionava como uma espécie de alojamento prisional onde era obrigatório exercer atividades laborais.

Essas workhouses são objetos das Leis dos Pobres que tiveram vigência na Inglaterra durante a Idade Moderna (século XIX). Sobre a forma de gestão administrativa para o atendimento de determinados grupos nessa época, Friedlander, apud Pereira (2008, p. 64), destaca a seguinte classificação acerca do tratamento em relação aos pobres:

[...] pobres impotentes (idosos, enfermos crônicos, cegos e doentes mentais), que deveriam ser alojados nas Poor-houses ou Almshouses (asilos ou hospícios); pobres capazes para o trabalho, ou mendigos fortes, que deveriam ser postos a trabalhar nas chamadas Workhouses; e os capazes para o trabalho, mas que se recusavam a fazê-lo (os corruptos), que deveriam ser encaminhados para reformatórios ou casas de correção.

As Leis dos Pobres dessa época instituíam essas medidas de repressão, mas tinham um falso discurso de promoção de ajuda e assistência aos pobres.

Bitencourt enfatiza que (2004, p. 21) "todos esses instrumentos refletem a influência dos conceitos religiosos e das orientações que guiavam a execução das penas que se imputavam no direito canônico".

A partir desse histórico da prisão é possível entender o atual sistema prisional brasileiro. Até os dias de hoje a validade da pena privativa de liberdade, adotada no país desde

\footnotetext{
${ }^{1}$ Jeremy Bentham nasceu em 15 de fevereiro de 1748 e faleceu em 6 de junho de 1832. Foi um filósofo e jurista inglês. Ajudou a difundir o utilitarismo, teoria ética que responde todas as questões acerca do que fazer, do que admirar e de como viver, em termos da maximização da utilidade e da felicidade. Foi responsável pela idealização do panoptismo, que corresponde à observação total, a tomada integral por parte do poder disciplinador da vida de um indivíduo. Foi quem primeiro utilizou o termo deontologia ('deon', dever + 'logos', ciência) para definir o conjunto de princípios éticos aplicados às atividades profissionais. (Wikipédia: a enciclopédia livre).
} 
o período colonial, é questionada, pois não tem sido o meio mais adequado para a reforma do infrator. Muitas são as críticas ao sistema de pena de prisão. Segundo Bitencourt (2004, p. 154):

\begin{abstract}
A crítica tem sido tão persistente que se pode afirmar, sem exagero, que a prisão está em crise. Essa crise abrange também o objetivo ressocializador da pena privativa de liberdade, visto que grande parte das críticas e questionamentos que se faz à prisão refere-se à impossibilidade - absoluta ou relativa - de obter algum efeito positivo sobre $\mathrm{o}$ apenado.
\end{abstract}

Além disso, vale destacar ainda as deficiências prisionais citadas por Bitencourt (2004, p. 156): maus-tratos, superlotação carcerária, falta de higiene, condições deficientes de trabalho, deficiência nos serviços médicos, regime alimentar deficiente, elevado índice de consumo de drogas, reiterados abusos sexuais e ambientes propícios à violência.

Essas críticas, que põem em relevo a questão da crueldade e da desumanização de um sistema que deveria ser reabiliatador, fizeram surgir mecanismos alternativos que sejam capazes de diminuir os problemas oriundos da pena privativa de liberdade. A esse respeito, algumas inovações já ocorreram no sistema jurídico brasileiro, para enfrentar esses problemas, como, por exemplo:

\begin{abstract}
A Lei 9.099, de 26 de setembro de 1995, que dispõe sobre os juizados Especiais Cíveis e Criminais, invertendo a regra geral do sistema até então vigente, dispõe em seu art. 62 que "o processo perante o Juizado Especial orientar-se-á pelos critérios da oralidade, economia processual e celeridade, objetivando sempre que possível a reparação do dano sofrido à vítima e a aplicação da pena não privativa de liberdade" (DOTTI, 1998, p. 94, grifos nossos).
\end{abstract}

Percebe-se assim que a pena privativa de liberdade está deixando de ser a punição prioritária utilizada pelo Estado. A função da pena no Estado Democrático de Direito deve ter como fundamento basilar a proteção do indivíduo e a garantia da função socioeducativa. Dotti (2004, p. 138) faz referência a doutrina de Mir Puig para tratar da função social da pena:

A função social da pena consiste na criação de possibilidades de participação nos sistemas sociais, oferecendo alternativas ao comportamento criminal. No dizer do mencionado penalista, este é o significado sociológico da função de ressocialização atribuída pelo direito positivo à execução das penas privativas de liberdade. 
É importante destacar a questão da possibilidade de participação, pois é por meio da integração social que o sujeito pode vir mudar o seu comportamento. Dessa análise, fica evidente que a pena de privação da liberdade não pode ser prioridade no Estado Democrático de Direito, que visa proteger valores fundamentais dos seres humanos.

As medidas alternativas à prisão também surgiram como possibilidade de minimizar os problemas presentes no sistema prisional brasileiro, como, "superlotação das prisões, alimentação deficiente, mau estado das instalações, pessoal técnico despreparado, falta de orçamento" (BITENCOURT, 2004, p. 203), dentre outras que representam o castigo desumano vivenciado nas cadeias.

Já existem estudos que comprovam que as alternativas penais, por não privarem o individuo de sua liberdade, representam meios mais eficazes de prevenção da reincidência criminal e de garantia socioeducativa para o autor do delito.

O Brasil aderiu o sistema penal que privilegia as penas não privativas de liberdade ao fazer parte das Regras de Tóquio, que são as regras mínimas das Nações Unidas sobre as medidas não privativas de liberdade.

\footnotetext{
As presentes Regras Mínimas enunciam um conjunto de princípios básicos para promover o emprego de medidas não-privativas de liberdade, assim como garantias mínimas para as pessoas submetidas a medidas substitutivas da prisão" (Regra de Tóquio, p.23).
}

As medidas alternativas têm respaldo em várias normas jurídicas do Brasil, tais como, a Lei 9.099 de 1995 (Juizados Especiais Cíveis e Criminais) e a Lei 9.714 de 1998 (que reformou a Parte Geral do Código Penal Brasileiro).

A Constituição Federal de 1988 (art. 98, inciso I) prevê a criação de juizados especiais para julgar infrações penais de menor potencial ofensivo atribuindo a possibilidade de aplicação de medida alternativa, como por exemplo a transação. Sobre esse aspecto Garcia (2005, p. 2) aponta um fato que merece destaque:

\footnotetext{
As críticas contra a lentidão do Judiciário e a impunidade dos infratores sensibilizaram os constituintes brasileiros, resultando na previsão constitucional de dispositivo que permitisse a apuração de pequenas infrações penais através dos procedimentos oral e sumaríssimo.
}

Dentro desse contexto, as medidas alternativas à prisão são meios eficazes de se prevenir a criminalidade e de promover tratamento social e educativo aos autores de delitos. 
Tem "por fim evitar o encarceramento de determinados criminosos, autores de infrações penais consideradas mais leves, provendo-lhes a recuperação através de restrições de certos direitos." (NUCCI, 2008, p. 406).

Mirabete (2007, p. 271), ao tratar do sistema de medidas alternativas diz:

\begin{abstract}
Diante da já comentada falência da pena privativa de liberdade, que não atende aos anseios da ressocialização, a tendência moderna é procurar substitutivos penais para essa sanção, ao menos no que se relacione com os crimes menos graves e aos criminosos cujo encarceramento não é aconselhável. O questionamento a respeito da privação de liberdade tem levado penalistas de numerosos países e a própria Organização da Nações Unidas a uma "procura mundial" de soluções alternativas para os infratores que não ponham em risco a paz e a segurança da sociedade.
\end{abstract}

A partir dessa argumentação, verifica-se que o mecanismo da medida alternativa vem sendo utilizado cada vez mais para substituir a pena privativa de liberdade, entendendo-se, conforme Capez (2005, p. 371), por medida alternativa:

[...] toda e qualquer medida que venha a impedir a imposição da pena privativa de liberdade, tais como, reparação do dano extintiva da punibilidade, exigência de representação do ofendido para determinados crimes, transação penal, suspensão condicional do processo, composição civil caracterizadora da renúncia ao direito de queixa ou representação etc. Não se trata de penas, mas de institutos que impedem ou paralisam a persecução penal, não se confundindo, portanto, com as penas alternativas (Grifos nossos).

Na concepção deste trabalho, a medida alternativa é diferente de pena alternativa, pois nem chega a ser considerada uma penalidade. A título de explicação é importante novamente recorrer a Capez (idem) para diferenciar medida alternativa de pena alternativa. Para Capez, penas altenativas "constituem toda e qualquer opção sancionatória oferecida pela legislação penal para evitar a imposição da pena privativa de liberdade. Ao contrário das medidas alternativas, constituem verdadeiras penas, as quais impedem a privação de liberdade".

No contexto das medidas alternativas, são de interesse do presente trabalho as modalidades da transação penal e da suspensão condicional do processo e os tipos de prestação pecuniária e prestação de serviço à comunidade explicitados no tópico seguinte e aprofundados no Capítulo II tendo como referência as categorias de análise já indicadas. 


\title{
1.2 Modalidades e Tipos de Medidas Alternativas
}

As modalidades de medidas alternativas à prisão são: a transação penal e a suspensão condicional do processo. Porém os tipos de medidas alternativas mais recorrentes na pesquisa foram: prestação pecuniária e prestação de serviço à comunidade.

A transação penal está disciplinada no artigo 76 da Lei 9.099 de 1995. Refere-se a crime de ação penal pública incondicionada, não sendo caso de arquivamento, em que o Ministério Público poderá propor a aplicação imediata de pena restritiva de direitos ou pecuniária, a ser especificada na proposta. Ela é proposta antes da instauração do processo criminal, pois precede a denúncia do Ministério Público.

A proposição da transação penal pelo Ministério Público é discricionária no sentido de que,mesmo presente a materialidade do crime e havendo os indícios de autoria, o órgão ministerial não é obrigado a denunciar.

Os requisitos para a propositura da transação estão no art. $76 \S 2^{\circ}$ da lei citada.

$\S 2^{\circ}$ Não se admitirá a proposta se ficar comprovado:

I - ter sido o autor da infração condenado, pela prática de crime, à pena privativa de liberdade, por sentença definitiva;

II - ter sido o agente beneficiado anteriormente, no prazo de cinco anos, pela aplicação de pena restritiva ou multa, nos termos deste artigo;

III - não indicarem os antecedentes, a conduta social e a personalidade do agente, bem como os motivos e as circunstâncias, ser necessária e suficiente a adoção da medida.

A suspensão condicional do processo é um instituto despenalizador, pois o processo instaurado é suspenso. Esse instituto está previsto no art. 89 da Lei 9.099 de 1995:

\begin{abstract}
Nos crimes em que a pena mínima cominada for igual ou inferior a um ano, abrangidas ou não por esta Lei, o Ministério Público, ao oferecer a denúncia, poderá propor a suspensão do processo, por dois a quatro anos, desde que o acusado não esteja sendo processado ou não tenha sido condenado por outro crime, presentes os demais requisitos que autorizariam a suspensão condicional da pena (art. 77 do Código Penal)".
\end{abstract}

Se o acusado e seu defensor aceitarem a proposta da suspensão condicional do processo, o processo ficará suspenso até que o autor do fato cumpra as condições previstas no art. $89 \S 1^{\circ}$, quais sejam: reparação do dano, salvo impossibilidade de fazê-lo; proibição de freqüentar determinados lugares; proibição de ausentar-se da comarca onde reside, sem 
autorização do Juiz; comparecimento pessoal e obrigatório a juízo, mensalmente, para informar e justificar suas atividades.

O Juiz tem a possibilidade de aplicar outras condições que fica subordinada a suspensão do processo, desde que sejam adequadas ao fato e à situação pessoal do acusado (art. 89, § $2^{\circ}$ da Lei 9.099/1995).

A suspensão condicional do processo poderá ser revogada se: o beneficiário vier a ser processado por outro crime ou não efetuar, sem motivo justificado, a reparação do dano; o acusado vier a ser processado, no curso do prazo, por contravenção, ou descumprir qualquer outra condição imposta. (art. $89 \S \S 3^{\circ}$ e $4^{\circ}$, Lei 9.099/1995).

Se o prazo da suspensão condicional estiver acabado e não houver revogação, será declarada extinta a punibilidade do autor, ou seja, ele não poderá mais ser punido (art. $89 \S$ $5^{\circ}$, Lei 9.099/1995). Se o acusado não aceitar a proposta prevista neste artigo, o processo prosseguirá em seus ulteriores termos (art. $89 \S 6^{\circ}$, Lei 9.099/1995).

Quanto às modalidades de medidas alternativas, serão explicitadas duas que foram mais recorrentes nesta pesquisa, quais sejam, a prestação pecuniária e a prestação de serviços à comunidade ou a entidades públicas.

A prestação pecuniária refere-se ao pagamento de valores em dinheiro efetuado "à vítima, a seus dependentes ou a entidade pública ou privada, com destinação social, de importância fixada pelo juiz" (MIRABETE, 2007, p. 273).

A permissão da prestação pecuniária consta no art. $49, \S 1^{\circ}$, do Código Penal Brasileiro. Contudo, o art. $45, \S 2^{\circ}$ permite que a doação seja feita como prestação de outra natureza e não somente em dinheiro. Neste caso, o beneficiário deve consentir com a doação, pois é ele quem irá utilizar os bens. Então, é preciso verificar a necessidade das organizações que irão receber a prestação (pecuniária ou de outra natureza).

Art. 45. Na aplicação da substituição prevista no artigo anterior, proceder-se-á na forma deste e dos arts. 46, 47 e 48.

$\S 1^{\circ}$ A prestação pecuniária consiste no pagamento em dinheiro à vítima, a seus dependentes ou a entidade pública ou privada com destinação social, de importância fixada pelo juiz, não inferior a 1 (um) salário mínimo nem superior a 360 (trezentos e sessenta) salários mínimos. O valor pago será deduzido do montante de eventual condenação em ação de reparação civil, se coincidentes os beneficiários.

$\S 2^{\circ}$ No caso do parágrafo anterior, se houver aceitação do beneficiário, a prestação pecuniária pode consistir em prestação de outra natureza. (Código Penal Brasileiro, grifos nossos). 
A prestação de serviços à comunidade ou a entidades públicas consiste, segundo o artigo 46, $\S 1^{\circ}$ do Código Penal Brasileiro, na atribuição de tarefas gratuitas ao condenado junto a entidades assistenciais, hospitais, orfanatos e outros estabelecimentos similares, em programas comunitários ou estatais.

\section{Prestação de serviços à comunidade ou a entidades públicas}

Art. 46. A prestação de serviços à comunidade ou a entidades públicas é aplicável às condenações superiores a seis meses de privação da liberdade.

$\S 1$ o A prestação de serviços à comunidade ou a entidades públicas consiste na atribuição de tarefas gratuitas ao condenado.

$\S 20$ A prestação de serviço à comunidade dar-se-á em entidades assistenciais, hospitais, escolas, orfanatos e outros estabelecimentos congêneres, em programas comunitários ou estatais.

$\S 30$ As tarefas a que se refere o $\S 1$ o serão atribuídas conforme as aptidões do condenado, devendo ser cumpridas à razão de uma hora de tarefa por dia de condenação, fixadas de modo a não prejudicar a jornada normal de trabalho.

$\S 4$ o Se a pena substituída for superior a um ano, é facultado ao condenado cumprir a pena substitutiva em menor tempo (art. 55), nunca inferior à metade da pena privativa de liberdade fixada.

Conforme Mirabete (2007, p. 274), a prestação de serviço corresponde "à pena de prestação social alternativa, admitida pela Constituição Federal (art. $5^{\circ}$, XLVI, d)" tal como afirma:

Segundo o legislador, o conjunto de ações, medidas e atitudes que objetivam a ressocialização do condenado não deve ser tarefa exclusiva do Estado, constituindo a participação da comunidade [...]. Por isso, a maior abrangência que a lei deu à aplicação dessa pena dependerá, e muito, do apoio que a comunidade der às autoridades judiciais, possibilitando a oportunidade para o trabalho do sentenciado, o que já demonstra as dificuldades do sistema adotado diante da reserva com que o condenado é encarado no meio social.

Dessa análise, é possível perceber que a prestação de serviço é um bom mecanismo para não privar a liberdade do indivíduo e para incentivá-lo ao convívio social, mas é preciso apoio da comunidade e das entidades para que se atinja o objetivo da educação e socialização.

Como já dito, o instituto da medida alternativa será melhor explicado e aprofundado no Capítulo II deste trabalho referente ao referencial teórico, já que é uma categoria de análise. 


\subsection{Central de Medidas Alternativas do MPDFT - SeMA/PJBZ}

O Ministério Público, segundo preceitua a Constituição Federal de 1988 em seu artigo 127, é instituição permanente, essencial à função jurisdicional do Estado, incumbindo-lhe a defesa da ordem jurídica, do regime democrático e dos interesses sociais e individuais indisponíveis. Logo, no Distrito Federal (DF), o Ministério Público contém uma Central de Medidas Alternativas (CeMA), criada para coordenar os Setores de Medidas Alternativas das Promotorias de Justiças das diversas Regiões Administrativas do DF. Esses Setores, por sua vez, são responsáveis pela execução e acompanhamento das referidas medidas.

O Setor de Medidas Alternativas da Promotoria de Justiça de Brazlândia (SeMA/PJBZ) foi inaugurado no mês de setembro do ano de 2004. Antes dessa inauguração foi feito, por meio da Coordenação Central de Medidas Alternativas, um curso de capacitação para os futuros servidores do SeMA de Brazlândia. Esse curso foi realizado entre 31 de janeiro de 2004 e 02 de julho de 2004 e continha duas partes: uma teórica e outra prática. O conteúdo ministrado englobou: missão e estrutura da CEMA; medidas alternativas e novos paradigmas; sistema penal brasileiro: conceito do Código Penal Brasileiro; procedimentos da CEMA (instrumentais); e estudos de caso sobre Relatório de Investigação Social e visita às instituições.

Após a inauguração do SeMA/PJBZ foi realizado o I Fórum para Instituições da Sociedade Civil sobre Medidas Alternativas na cidade de Brazlândia. Sentiu-se a necessidade de esclarecer as instituições da cidade sobre o tema utilizado no Setor. O público-alvo desse fórum consistiu de: instituições credenciadas para acompanhar medidas alternativas; operadores de justiça penal; instituições de ensino superior; estudantes do curso de direito, serviço social, psicologia, ciências sociais, biologia, engenharia ambiental e áreas afins; e sociedade civil interessada no tema de medidas alternativas. Nesse fórum foram apresentadas as seguintes temáticas: conceito de medida alternativa; papel da comunidade na justiça penal; situação das instituições no contexto da aplicação de medidas alternativas; relacionamento entre as instituições e os autores do fato; vivência das medidas alternativas nas instituições; outras formas de aplicação de medidas alternativas: entorpecentes, maus tratos, meio ambiente.

O SeMA/PJBZ é responsável por dar um suporte à Promotoria de Justiça e tem como função aplicar e acompanhar medidas alternativas que são aplicadas a processos cujo delitos são de pequeno potencial ofensivo e cabem aplicação de medida alternativa. Para garantir o 
cumprimento da medida alternativa, o SeMA/PJBZ também possui a função de credenciar a acompanhar as instituições responsáveis por receber os autores do fato por meio de uma parceria com essas instituições(governamentais ou não-governamentais).

Apesar de não ser objeto central deste trabalho, é importante destacar que o agir profissional dentro do Setor de Medidas Alternativas é bastante válido para a formação do profissional de Serviço Social, pois no seu dia-a-dia a profissão lida com meios de intervenção, parcerias da rede social e principalmente, com várias demandas e necessidades sociais.

A CeMA emitiu, no ano de 2006, um "Retrato de Penas e Medidas Alternativas", que contem estatísticas que merecem destaque por revelarem a aplicação do instituto da medida alternativa.

São $82,19 \%$ os delitos que estão tendo aplicação de medida alternativa, sendo possível perceber que os regimes privativos de liberdade tiveram uma considerável diminuição.

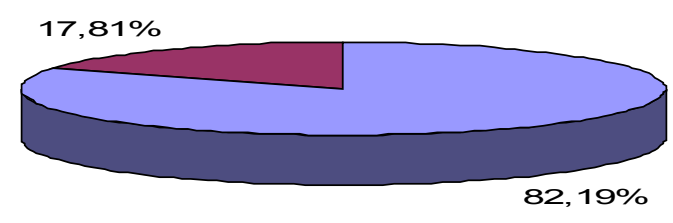

Esse Retrato mostra também que a escolaridade predominante de pessoas que cometem delitos, passíveis de medidas alternativas, é o ensino fundamental incompleto, representando uma porcentagem de $41,16 \%$ em 2005. É importante observar que somente $4,45 \%$ do total de pessoas que cometem delitos desse tipo conseguem chegar ao ensino superior e $3,82 \%$ conseguem concluí-lo.
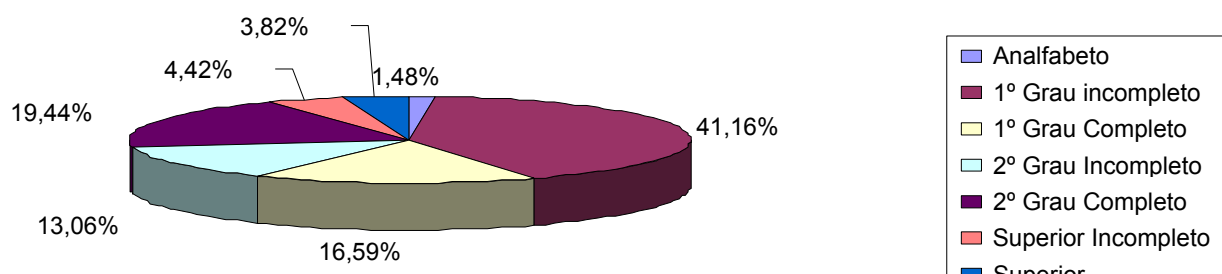
No tocante à situação de desemprego, os mesmos dados refletem a situação econômica dos autores do fato. Assim, das pessoas que cometem delitos, 29,47\% são desempregadas.

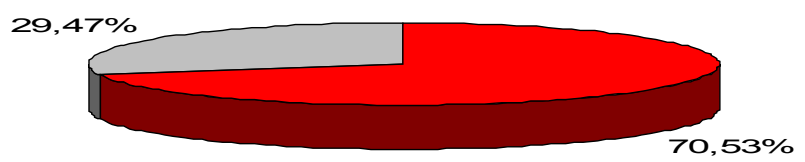

$\square$ Empregado

$\square$ Desempregado

Essas estatísticas feitas pela CeMA são importantes no sentido de situarem a medida alternativa na realidade em que ela está sendo aplicada, e principalmente de permitirem a visualização do desenvolvimento do instituto.

As Regras de Tóquio, formalmente denominadas Regras Mínimas das Nações Unidas sobre Medidas não-privativas de Liberdade, foram criadas pela Organização das Nações Unidas (ONU) com fundamento na Declaração Universal dos Direitos do Homem e no Pacto Internacional sobre Direitos Civis e Políticos. Estas regras têm por finalidade estabelecer determinações mínimas a serem seguidos pelos Estados que desejarem instaurar sistemas penais que permitam a presença de penas não privativas de liberdade como forma de solução contra a criminalidade.

\footnotetext{
As medidas não privativas de liberdade não restringem, tanto quanto a prisão, a liberdade do delinqüente. Este não precisa deixar sua família ou comunidade, abandonar suas responsabilidades ou perder seu possível emprego. Apesar disto, os delinqüentes submetidos à medida não-privativa de liberdade podem ficar sujeitos a várias condições, restrições e exigências (REGRA DE TÓQUIO, 1998, p.20).
}

A medida alternativa como substituta da pena privativa de liberdade, tem, pois, como principal objetivo contribuir para a adequada integração dos infratores na sociedade. A experiência do Setor de Medidas Alternativas da Promotoria de Justiça de Brazlândia auxilia a visualizar as etapas de aplicação e acompanhamento da medida alternativa.

"No Brasil, para que haja o desenvolvimento e consolidação das penas e medidas alternativas à prisão, com instâncias de reintegração social, é necessária uma conexão entre serviços e políticas de diferentes ordens" (BISCAIA e SOUZA, 2005, p. 128). Mas percebe- 
se que, na prática da execução e do acompanhamento dessas medidas não há garantia de utilização de serviço e políticas sociais. Este fato prejudica a reintegração na sociedade do autor do fato, pois ele continua na situação sócio-econômica que tinha na época em que cometeu o delito, não conseguindo assim melhorar a sua condição de vida e de cidadania. Dessa feita, a integração entre a aplicação da medida alternativa e os serviços e políticas sociais constitui uma proposta em aberto e a sua não realização reflete uma das limitações que o Estado e a sociedade devem enfrentar.

É nesse sentido que se situa o interesse desta pesquisa. Pois, apesar da medida alternativa à prisão ser um instituto que não priva a liberdade do sujeito, ela deve garantir ao autor do fato qualidade de vida e usufruto de direitos sociais. Portanto busca-se descobrir o significado e a contribuição social da medida alternativa.

\subsection{Abordagem Teórico-Metodológica}

Cronologicamente, as etapas da pesquisa foram divididas em cinco: a) levantamento bibliográfico e revisão de literatura sobre o significado e alcance socioeducativo das medidas alternativas à prisão; b) realização das entrevistas com os autores do fato; c) elaboração do instrumental de coleta de dados (questionário) para obtenção de informações junto às instituições, servidor do SeMA/PJBZ e Promotor de Justiça; d) aplicação dos questionários; e) análise quantitativa e qualitativa dos dados coletados.

A pesquisa de campo foi realizada no Setor de Medidas Alternativas da Promotoria de Justiça de Brazlândia.

O presente tópico tem por objetivo apresentar o método da pesquisa, critérios de seleção dos participantes e as técnicas e instrumentos utilizadas na coleta de dados.

\subsubsection{Método da Pesquisa}

O método utilizado na pesquisa teve caráter relacional-dialético, pois se pretendia obter conhecimento e compreensão de um conjunto de processos organicamente interligados entre si e mutuamente influentes. A análise das relações entre determinações estruturais e históricas, a observação do papel dos sujeitos e a passagem do que é aparente para o que não é 
visível sem investigação, constituíram passos necessários para se apreender o objeto de estudo na sua dinamicidade. (MARCONI e LAKATOS, 2007, p. 100).

\subsubsection{Critérios para Seleção dos Participantes da Pesquisa}

“A amostra é uma parcela convenientemente selecionada do universo (população); é um subconjunto do universo" (Idem, p. 165)

Os sujeitos desta pesquisa, que constituíram amostra pesquisada, foram divididos em três categorias de acordo com a função que exercem no processo de aplicação e acompanhamento da medida alternativa: 10 (dez) autores do fato, duas instituições, um servidor do SeMA/PJBZ e um Promotor de Justiça. Esses informantes foram escolhidos por possuírem vivências e informações qualificadas sobre a medida alternativa à prisão.

Os autores do fato e as duas instituições que participaram da pesquisa foram escolhidos aleatoriamente. Porém, do universo das instituições parceiras elegeu-se uma pública e outra privada, com a finalidade de averiguar se há diferenças e similaridades entre esses dois setores no cumprimento da medida alternativa. Já o servidor do SeMA/PJBZ e o Promotor de Justiça foram escolhidos por estarem diretamente trabalhando com o instituto da medida alternativa no Setor de Medidas Alternativas da Promotoria de Justiça de Brazlândia.

\subsubsection{Técnicas e Instrumentos para Coleta de Dados}

Na fase de coleta de dados foram utilizados dois tipos de fontes: secundária ou indireta e primária ou direta. Como fontes secundárias foram consideradas obras e textos relacionados ao tema, partindo-se da bibliografia básica já pesquisada. Também foram utilizados documentos do CeMA, tais como: regimento interno, retrato das penas alternativas e cartilha de orientação sobre medidas alternativas.

Quanto à fonte direta, a pesquisa de campo foi privilegiada e realizada na unidade do Setor de Medidas Alternativas de Brazlândia, com os autores de fato, as instituições parceiras e o Promotor de Justiça. Foram realizadas entrevistas com autores do fato que cumpriram a medida alternativa. A aplicação de questionário com responsáveis pelas instituições que recebem os autores do fato para cumprir medida alternativa teve o objetivo de identificar o 
papel dessas instituições como possíveis colaboradores do processo socioeducativo. O questionário também foi utilizado para coleta de informações do Promotor de Justiça e do servidor do SeMA/PJBZ, que fazem parte do processo investigado.

A técnica de observação também foi utilizada, uma vez que houve verificação in loco no próprio SeMA/PJBZ e nas instituições parceiras do objeto investigado, ao ser realizado o estágio supervisionado da pesquisadora. A partir da observação foi possível conhecer os atores que fazem parte do processo de aplicação e acompanhamento da medida alternativa, bem como perceber o desenvolvimento desse processo. Foi por meio da técnica de observação que se tornou possível validar as informações obtidas nas entrevistas instrumentalizadas por questionários.

As entrevistas com os autores do fato foram realizadas em uma amostra aleatória, mas representativa do universo. No total, dez autores do fato que cumpriram medida alternativa responderam as entrevistas, e foram escolhidos a partir dos relatórios dos atendimentos. $\mathrm{O}$ instrumental utilizado na realização das entrevistas já existia no CeMA, porém foram feitas adaptações para se adequar a pesquisa. É importante salientar que esse instrumental ainda não tinha sido aplicado em Brazlândia. As entrevistas foram padronizadas, visto terem sido elaboradas de forma estruturada com perguntas fechadas.

$\mathrm{O}$ questionário aplicado junto às instituições, ao servidor do SeMA/PJBZ e ao Promotor de Justiça foi elaborado com perguntas abertas para serem respondidas livremente de maneira escrita. Os instrumentais relativos aos questionários foram elaborados para fins dessa pesquisa.

A pesquisa valeu-se de análise tanto quantitativa quanto qualitativa, pois, para analisar a função socioeducativa da medida alternativa foi preciso obter dados estatísticos e realizar análise e interpretação desses dados. 


\section{Capítulo II}

\section{Referencial Teórico}

Quando se fala de medida alternativa à prisão está se considerando um fato cometido que não chega a ser tratado como crime por não ter um processo judicial finalizado. Assim, a medida alternativa não pode ser considerada uma pena, pois ninguém pode ser punido sem o trânsito em julgado da sentença condenatória (Artigo $5^{\circ}$, inciso LVII, da Constituição Federal). Portanto, medida alternativa é um acordo entre o autor do fato e o Estado (representado pelo Juiz) para que não se instaure ou se interrompa o processo.

Ao tratar da transação penal, Garcia (2005, p. 88) considera medida alternativa um acordo de vontades: "deve ocorrer um acordo de vontades entre quem acusa e aquele a quem é imputada a autoria do fato, cabendo ao magistrado proferir sentença homologatória sobre o que foi acordado".

O crime, em sentido amplo, é uma conduta humana que provoca um resultado que contraria o ordenamento jurídico. Para que seja aplicada uma pena ao agente que praticar conduta criminosa é preciso que, no fato ocorrido, esteja presente o elemento da culpabilidade. Essa culpabilidade não se refere à culpa e ao dolo do agente, pois esses elementos já estão inseridos na definição do crime; mas sim, à análise das condições jurídicas que permitem a punição. Por exemplo, se o agente possui menos de dezoito anos de idade, pode ter cometido um crime ${ }^{2}$, mas não pode ter uma aplicação de pena sobre a sua conduta, por ser inimputável e não estar presente a culpabilidade. Nesse caso, ficará sujeito às normas estabelecidas na legislação específica, qual seja o Estatuto da Criança e do Adolescente (Lei 8.069 de 1990).

O Direito Penal é a última forma de controle social ${ }^{3}$ a ser utilizada pelo Estado a fim de solucionar os conflitos da sociedade (princípio da intervenção mínima do direito penal), ou seja, se outros ramos forem ineficazes, utiliza-se o direito penal. Só haverá presença do direito penal quando a lei descrever o fato praticado como sendo crime. Segundo Capez (2005, p. 22), "a intervenção mínima e o caráter subsidiário do direito penal decorrem da dignidade

\footnotetext{
2 "Considera-se ato infracional a conduta descrita como crime ou contravenção penal”. (Artigo 103, Estatuto da Criança e do Adolescente).

${ }^{3}$ Usualmente o controle social denomina tanto o controle que o Estado exerce sobre a sociedade, quanto o que a sociedade exerce sobre o Estado. Estabelecendo uma distinção, Pereira (2007, p. 7) afirma que o controle da sociedade sobre o Estado é melhor denominado como controle democrático, pois expressa melhor o movimento de "regulação pelos cidadãos, do Estado e de instituições da sociedade, com vista à ampliação da democracia".
} 
humana, pressuposto do Estado Democrático de Direito, e são uma exigência para a distribuição mais adequada da justiça".

A aplicação da pena existe como resposta estatal perante as condutas reprovadas socialmente. A pena é um tipo de sanção penal imposta pelo Estado à pessoa culpada pela prática da infração penal. Segundo a teoria eclética da finalidade da pena, a sanção penal tem tanto a função de punir o criminoso, quanto de prevenir a prática do crime (CAPEZ, 2005, p. 346). Mas, no Brasil, essa sanção também tem o objetivo de confortar a sociedade com a prisão do criminoso, não havendo assim profunda preocupação com a prevenção da prática delituosa e com a recuperação do agente do delito.

Por esta razão, o Estado limita-se a elaborar leis e punir os infratores, gerando, assim, a falsa idéia de que a sociedade está protegida. O Poder Público não se preocupa em garantir direitos sociais (educação, trabalho, saúde, moradia, etc.). Se a população não tem seus direitos garantidos pelo Estado, tenta buscar meios alternativos para satisfazer suas necessidades humanas, sendo a criminalidade um desses meios. "O que se tem que ver é como evitar que o crime seja cometido, através da melhoria das condições de vida do povo." (LINS e SILVA, 1997).

O sistema penitenciário brasileiro é "a organização criada pelo Estado para a execução das sanções penais que importem na privação ou restrição da liberdade individual" (NEUMAN apud DOTTI, 1998, p. 116). Neuman afirma ainda que esse sistema penitenciário é responsável por renovar, anular ou neutralizar os fatores relevantes de inadaptação social dos infratores. A partir dessa análise fica constatado que o sistema penitenciário brasileiro não é capaz de reabilitar e recuperar os agentes dos crimes.

Nessa perspectiva crítica é possível evidenciar que o sistema penitenciário está sofrendo fortes degradações, caracterizadas por superlotação das cadeias, condições desumanas de subsistência, falta de recursos humanos, financeiros e materiais, dentre outros motivos que se relacionam diretamente com a violação dos direitos humanos. Dotti (1998, p.117) afirma que "a decadência da instituição carcerária é somente a ponta do iceberg a mostrar a superfície da crise geral do sistema, para o qual convergem muitos outros fatores".

A medida alternativa surge como um instituto processual capaz de minimizar os problemas evidenciados do sistema prisional e com a principal finalidade de garantir uma função socioeducativa para o autor do fato delituoso. É um instituto que fornece oportunidade para o infrator que comete delitos de pequeno potencial ofensivo. Para Garcia (2005, p. 88), a medida alternativa serve para "desafogar o judiciário e promover a paz social desejada". 
Sanchéz (2002) estabelece a existência de três velocidades para o direito penal. O Direito Penal de primeira velocidade diz respeito ao modelo liberal-clássico, que se utiliza preferencialmente da pena privativa de liberdade. O Direito Penal de segunda velocidade incorpora duas tendências, quais sejam, a flexibilização proporcional de determinadas garantias penais e processuais aliada à adoção das medidas alternativas à prisão (penas restritivas de direito, pecuniárias etc.). No Brasil, esse instituto começou a ser introduzido com a Reforma Penal de 1984 e se consolidou com a edição da Lei dos Juizados Especiais (Lei n. 9.099, de 1995), que é o foco do presente trabalho. Já o Direito Penal de terceira velocidade é uma interação das características do de primeira e de segunda velocidade. Ou seja, pode basear-se na pena privativa de liberdade (Direito Penal de primeira velocidade), mas é maleável às formas alternativas à prisão (Direito Penal de segunda velocidade).

A utilização da medida alternativa deve estar articulada às políticas públicas para garantir direitos sociais e acesso aos serviços pelos autores do fato. O Ministério Público, com o advento da Constituição Federal de 1988, tem a função de defender a ordem jurídica, o regime democrático e os interesses sociais e individuais indisponíveis (Artigo 127, Constituição Federal).

Além da participação efetiva do Estado, para ter a verdadeira função socioeducativa da medida alternativa é preciso o controle democrático da comunidade nas questões de Direito Penal. Sobre isso, diz Dotti (1998, p. 134):

\footnotetext{
A participação da comunidade nas questões de Direito Penal jamais poderia se caracterizar pela mera possibilidade, formalmente tolerada, mas pela probabilidade real de atuação junto aos poderes decisórios. As instâncias informais de controle social, onde a família, as entidades de ensino, as associações de classe e outras coletividades possam livremente instituir grupos de pressão, em seu mais vigoroso sentido de representação popular [...].
}

Para tornar mais precisa a análise da medida alternativa, sua função socioeducativa, a importância de articulação com as políticas públicas e a necessidade de controle democrático nas questões de direito penal, faz-se necessário explicitar as seguintes categorias de análise: medida alternativa, função socioeducativa e direitos sociais.

\subsection{Medida Alternativa}


Antes de explicitar a medida alternativa, faz-se necessário estabelecer a distinção entre medida alternativa e pena alternativa. Segundo Barroso (2003, p. 84), a pena alternativa é uma opção de sanção para ser evitada a privação de liberdade, podendo-se apresentar como exemplos a pena restritiva de direitos e a de multa. Já a medida alternativa não é considerada punição ou sanção, pois sequer o autor do fato é julgado e sentenciado. Medida alternativa é, portanto, uma opção ao encarceramento, sendo arquivado o processo com o cumprimento das condições estabelecidas.

Duas são as modalidades principais de medidas alternativas: transação penal e suspensão condicional do processo.

A transação penal e a suspensão condicional do processo foram inseridas no ordenamento jurídico brasileiro por meio da Lei dos Juizados Especiais Cíveis e Criminais (Lei 9.099 de 1995). E tem como pressupostos a efetivação concreta dos princípios da oralidade, simplicidade, informalidade, economia processual e celeridade (artigo 62, da Lei 9.099 / 1995).

O princípio da oralidade diz respeito à possibilidade de praticar atos processuais de forma oral, gerando não a exclusão da escrita, mas a sua diminuição. O princípio da simplicidade se refere a não utilização de sistemas burocráticos para o andamento do processo, sem que fique prejudicada a prestação jurisdicional. O princípio da informalidade coloca alguns atos processuais formais como desnecessários por gerar morosidade. $\mathrm{O}$ princípio da economia processual é uma forma de se evitar gastos desnecessários, tanto para o Estado como para as partes, realizando-se os atos processuais em uma única audiência. Por fim, o princípio da celeridade processual significa a necessidade de se imprimir presteza e rapidez nos atos processuais (TOURINHO NETO, 2002).

A transação penal é um instituto proposto pelo Ministério Público ao autor de delitos de menor potencial ofensivo, para que haja possibilidade de arquivamento do processo diante do cumprimento de condições estabelecidas. Na transação penal ainda não houve a acusação formal do acusado por parte do órgão ministerial. Assim, caso o infrator cumpra integralmente a medida, essa conduta praticada não constará como antecedente criminal, gerando o arquivamento do feito.

Delitos de menor potencial ofensivo são os que a lei estabelece uma pena máxima não superior a dois anos, acumulada ou não com multa ${ }^{4}$. Exemplo: lesão corporal simples, que

\footnotetext{
${ }^{4}$ Esse dispositivo sofria controvérsia quanto à quantidade de pena máxima para se definir os delitos de menor potencial ofensivo. No ano de 2006, a Lei 11.313 alterou a Lei 9.099 de 1995 e estabeleceu a pena máxima como sendo não superior a dois anos, finalizando assim qualquer tipo de controvérsia.
} 
tem pena prevista de detenção de três meses a um ano, no caput do artigo 129 do Código Penal Brasileiro.

Somente o próprio autor do fato pode aceitar a transação penal, sendo-lhe facultada a possibilidade de recusá-la - situação em que o juiz determinará a continuidade normal do processo, podendo o autor do fato, ao final da lide, ser condenado ou absolvido. É importante destacar que a vítima não participa da proposta da transação penal.

Não se admitirá a proposta da transação penal se ficar comprovado que: o autor da infração foi condenado, por prática de crime, à pena privativa de liberdade por sentença definitiva; o agente foi beneficiado anteriormente, no prazo de cinco anos, pela aplicação de pena restritiva ou multa; os antecedentes, a conduta social e a personalidade do agente, bem como os motivos e as circunstâncias, não indicarem ser necessária e suficiente a adoção da medida. (Lei 9.099 de 1995, art. 76, § $2^{\circ}$ ). Sobre esse assunto, Garcia (2005, p. 89) assim se expressa:

\footnotetext{
Se por negligência ou por qualquer outra circunstância acontecer a transação penal, devidamente homologada, apesar da existência da causa impeditiva não constatada, deve prevalecer a transação. Ela não pode ser anulada nem revogada, prejudicando o autor do fato [...].
}

Por conseguinte, mesmo havendo algum impedimento para a transação penal, se esta for proposta e aceita, não poderá ser anulada ou revogada, prejudicando o autor do fato.

É importante ressaltar que, na transação penal, o autor do fato ainda não foi denunciado nem processado. Já na suspensão condicional do processo (Lei 9.099 de 1995, art. 89), o autor foi denunciado e está sendo processado, mas houve interrupção do curso do processo até o autor cumprir as condições estabelecidas. Assim, enquanto na transação penal o objetivo a ser atingido é a possibilidade do autor do fato não vir a ser denunciado, na suspensão condicional do processo o intuito é evitar a execução da pena.

A propositura da suspensão condicional também é feita pelo Ministério Público e deve obedecer às seguintes condições: a pena mínima cominada ser igual ou inferior a dois anos; não existir outro processo em que se teve denúncia contra o autor do fato; o autor não ter sido condenado por outro crime; a culpabilidade, os antecedentes, a conduta social e a personalidade do agente, bem como os motivos e as circunstâncias, autorizarem a concessão do benefício. 
Conforme disciplinado no artigo $89, \S 1^{\text {o }}$, da Lei 9099/95, a proposta da suspensão condicional do processo deverá ser aceita, diante do Juiz, tanto pelo acusado quanto pelo seu defensor. Caso um deles não aceite a proposta, o processo seguirá normalmente. Esse aspecto difere da transação penal, pois, como já dito, neste caso somente o autor do fato poderá aceitar o benefício.

No instituto da transação penal, as condições não estão estabelecidas em lei, portanto surge a possibilidade de o autor do fato e o Ministério Público convencionarem a medida que melhor se ajuste ao caso em comento. $\mathrm{Na}$ suspensão condicional, também existe a possibilidade de se convencionar medidas, mas algumas condições são de aplicabilidade obrigatória por força da lei, tais como: reparação do dano, proibição de freqüentar determinados lugares, proibição de ausentar-se da comarca onde reside, comparecimento pessoal e obrigatório a juízo para informar e justificar suas atividades.

No $\S 2^{\circ}$ do artigo 89 da lei supracitada, consta que: “O Juiz poderá especificar outras condições a que fica subordinada a suspensão, desde que adequadas ao fato e à situação pessoal do acusado".

É importante destacar que a suspensão condicional do processo abrange mais delitos do que apenas o de menor potencial ofensivo, pois são considerados também crimes cuja pena mínima não seja superior a um ano. A esse respeito, Garcia (2005, p. 149) afirma:

A possibilidade de suspensão do processo, também conhecida como "sursis antecipado", não é destinada apenas para as infrações de menor potencial ofensivo, mas também para todas as infrações cuja pena mínima não for superior a um ano.

Nesse sentido, a suspensão condicional do processo abrange mais crimes para ser aplicada do que a transação penal, pois esta se limita a delitos de pequeno potencial ofensivo.

Nas duas modalidades citadas de medida alternativa, o cumprimento das condições estabelecidas gera arquivamento do feito e o autor não será mais punido pelo fato praticado. Contudo, há que lembrar que, caso haja descumprimento por parte do autor do fato, o benefício será revogado, ensejando a continuidade do feito. Na suspensão condicional, o benefício também pode ser revogado se o acusado for processado por outro crime no prazo estipulado pelo magistrado (dois ou quatro anos).

A medida alternativa não beneficia apenas o autor do fato, mas também a sociedade em geral, pois descongestiona o judiciário, haja vista a enorme quantidade de processos, bem como diminui a população carcerária, fornecendo mais oportunidade para quem praticou o delito de não ser privado do convívio social. Isso, além de ser mais justa. 
São dois os tipos mais comuns de medidas alternativas aplicadas: a prestação de serviço à comunidade e a prestação pecuniária, que estão conceituados no Código Penal. $\mathrm{O}$ primeiro está previsto no artigo $46, \S 1^{\circ}$ do Código Penal: “A prestação de serviços à comunidade ou a entidades públicas consiste na atribuição de tarefas gratuitas ao condenado". E a prestação pecuniária tem base legal fundada no artigo $45, \S 1^{\circ}$ do Código Penal Brasileiro: “A prestação pecuniária consiste no pagamento em dinheiro à vítima, a seus dependentes ou a entidade pública ou privada com destinação social, de importância fixada pelo juiz".

A medida alternativa é um recurso utilizado e acompanhado por uma unidade do Ministério Público do Distrito Federal e Territórios denominada Central de Medidas Alternativas. Essa unidade é formada por uma coordenação central e por setores regionais que se localizam em várias Regiões Administrativas do Distrito Federal.

Com o objetivo de difundir o conhecimento do Ministério Público, dar continuidade à dinâmica de atendimentos aos cidadãos e assessorar Promotores de Justiça, a CeMA foi criada em 2001 como um projeto piloto na Promotoria de Justiça de Ceilândia. A criação deste projeto teve a participação do professor doutor e integrante do Conselho de Pesquisadores da CeMA, Vicente Faleiros.

Os setores regionais, chamados de Setores de Medidas Alternativas (SeMA), têm por objetivo auxiliar a CeMA na aplicação e execução de medidas alternativas efetivas, juntamente com outros setores especializados: Setor de Investigação Social para Delitos de Entorpecentes, Violência Doméstica e Maus-Tratos (SISDEV) e Setor de Investigação Social para Delitos de Meio Ambiente, Ordem Urbanística e Patrimônio Público (SISDEMA).

Para que o trabalho feito pelos profissionais da CeMA e do Setores, regionais e especializados, seja realizado da melhor forma, foi construído pelo Tribunal de Justiça e aprovado pelo Ministério Público, a chamada Rede Social. Esta rede é constituída de entidades, governamentais ou não, credenciadas e que possuem interesse em auxiliar a aplicação e execução das medidas alternativas.

Os instrumentos utilizados pelos Setores que compõem a CeMA para acompanhar e executar as medidas alternativas são:

\section{- Relatório de Investigação Social (RIS)}

É elaborado antes do início da medida alternativa e tem por objetivo principal adequar a realidade social (perfil socioeconômico) do autor do fato à medida a ser aplicada e à instituição que o receberá. É feita uma entrevista com o autor do fato e, a partir das 
informações coletadas, será elaborado o RIS. Existe um roteiro das perguntas principais a serem utilizadas, porém, de acordo com as respostas e com a própria realidade social da demanda, outros tipos de questionamentos vão se tornando necessários. Esse roteiro de perguntas serve apenas para direcionar a entrevista, pois é possível e ao mesmo tempo necessário saber formular outros tipos de questões para melhor captar o perfil socioeconômico do autor do fato.

Depois de elaborado um resumo das informações fornecidas pelo autor, o profissional que o entrevistou tenta encontrar uma medida que seja compatível tanto com a realidade analisada, quanto com o delito cometido. Não há obrigatoriedade de este profissional ter nível superior e, por isso, normalmente, as entrevistas são realizadas por técnicos. Ao final do RIS, é feita uma sugestão de medida alternativa para a Promotoria de Justiça, e o Promotor a acatará ou não. Nessa sugestão, deve estar especificado o tipo de medida a ser aplicada. Se for doação, a sugestão deverá prever: a quantidade a ser doada; a quantidade de parcelas do pagamento; as datas de cada parcela e a instituição que receberá a doação. Se for prestação de serviço, deverá estar especificado: a quantidade de horas trabalhadas; o período para cumprir essas horas e a instituição que receberá o prestador de serviço.

$\mathrm{Na}$ entrevista com o autor do fato, muitas vezes percebe-se alguns problemas sociais e econômicos que podem estar ou não relacionados ao fato gerador do delito. Muitos desses problemas são passíveis de resolução, por meio de encaminhamentos feitos pelo Setor para outras entidades parceiras do MPDFT. Normalmente, com a elaboração do RIS também são produzidos alguns ofícios para as instituições parceiras tentarem resolver os problemas identificados.

A instituição que recebe o autor do fato, para que nela ele cumpra a medida alternativa, deve ser cadastrada no CeMA e ter compromisso com a efetiva integração social , do autor. A cada seis meses é realizada, pela equipe dos setores regionais, uma visita a todas as instituições cadastradas para orientá-las quanto ao tratamento dos casos de medidas alternativas e à atualização de seus procedimentos.

É na instituição, na qual o autor do fato cumpre a medida alternativa, que mais pode ou não ficar evidente o significado e a contribuição desta medida; pois é neste local que ele presta algum benefício à sociedade, tendo a oportunidade de cumprir a medida e tomar consciência do motivo desse cumprimento, na convivência social dentro da instituição.

A instituição, por seu turno, deve ter compromisso com o Estado e o autor do fato, no sentido de respeitar a medida, que é combinada na audiência, não exigindo mais do que o 
acordado e realizando a fiscalização da medida alternativa de forma a repassar as informações sobre o seu cumprimento para serem anexadas ao processo. A instituição não pode tratar o autor do fato de forma preconceituosa e desumana, devendo contribuir para a socioeducação do autor do fato.

\section{- Relatório de Evolução na Execução da Medida (REEM)}

Este relatório é elaborado quando já existe medida imposta e há descumprimento da mesma por parte do autor do fato; ou seja, quando há necessidade de se apresentar nova proposta devido à incompatibilidade entre a realidade do autor do fato e a medida a ser cumprida. Em alguns casos, apenas é preciso conscientizar e esclarecer o autor sobre a medida alternativa, pois há aqueles que não a cumprem por não entenderem a importância e a necessidade de seu cumprimento. Neste caso, a equipe do setor regional orienta o autor sobre a medida e explica as conseqüências de seu não cumprimento. Se aceito pelo Promotor de Justiça, o próprio setor encaminha o autor do fato para a instituição para dar continuidade ou iniciar o cumprimento da medida. A instituição que o receberá deverá ter os mesmos compromissos indicados acima.

Uma informação que deve estar presente no REEM é a justificativa do não cumprimento da medida, quando for o caso; e, a partir dessa justificativa e da análise do perfil socioeconômico do autor, apresentar uma nova sugestão de medida a ser cumprida.

Além disso, na coleta de dados para elaboração do REEM, podem ser feitos encaminhamentos para possível resolução de problemas identificados. É importante ressaltar que os ofícios enviados para as instituições sempre requerem resposta que indique qual foi a atuação naquele caso concreto.

O profissional responsável por elaborar o REEM tem que se certificar que o autor do fato se comprometeu em cumprir integralmente a medida e que entendeu as conseqüências do não cumprimento da mesma, quais sejam: suspensão do benefício da medida alternativa e impossibilidade do arquivamento do processo, podendo este vir a ter continuidade.

\section{- Informações do Setor de Medidas Alternativas (ISMA)}

O ISMA é elaborado quando o Setor de Medidas Alternativas tem algum comunicado para a promotoria em relação ao processo, desde que não seja informação da realidade social do autor e nem do descumprimento da medida imposta, pois esses assuntos são objetos do 
RIS e do REEM, respectivamente. Um exemplo de informação para ser inserido no ISMA é a de que o Setor não encontrou o autor do fato, não sendo possível realizar a intervenção.

\section{- Outros Instrumentais}

A partir da construção dos três tipos de relatórios acima descritos e da análise da realidade social dos usuários, os Setores, regionais e especializados, utilizam outros instrumentais para melhor proceder a sua intervenção. Dentre esses, está a elaboração de ofícios de encaminhamentos para instituições que têm possibilidade de contribuir com uma resolução para o problema identificado. Por esse motivo, a relação entre o Ministério Público, instituições parceiras e sociedade deve ser bem estruturada.

\subsection{Função Socioeducativa}

O termo socioeducativo está sendo empregado e discutido no âmbito das ações sociais junto a adolescentes e jovens em conflito com a lei, no sentido de que, em vez de cumprirem pena, como se fossem adultos, cumprem medida socioeducativa em relação a delitos denominados atos infracionais, e não crime.

Pretende-se, no presente trabalho, utilizar o conceito socioeducativo, mas com certa distinção do que é utilizado junto a adolescentes e jovens supra mencionados. No caso desse segmento, o conceito socioeducativo é referenciado a qualquer ato infracional, independente de ser de pequeno ou grande potencial ofensivo. Ou seja, se um adolescente cometer homicídio e, um outro, um furto banal, ambos cumprem medida socioeducativa. Mas a medida alternativa com função socioeducativa para os adultos só é cabível em casos de delitos de pequeno potencial ofensivo.

Entretanto, mesmo com essa diferenciação, é possível utilizar o conceito de função socioeducativa para ambos os casos.

O trabalho profissional como caráter educativo é antigo na área da Assistência Social e surgiu para ser uma forma de socialização e domesticação do trabalhador pobre nas décadas de 1930 e 1940. Nesta época, o capitalismo urbano-industrial estava em expansão e havia a noção de que o pobre era culpado pela situação em que vivia. Assim, as experiências socioeducativas tinham por responsabilidade ajustar o indivíduo para que não se desviasse do caminho imposto como correto. A função socioeducativa do trabalho surge "[...] para 
desenvolver habilidades que possibilitassem o enquadramento social dos trabalhadores pobres às novas necessidades criadas pela modernização capitalista." (CADERNO DE CONCEPÇÃO, 2008, p. 46). Tratava-se de uma forma de adequação de novos padrões que surgiram com o advento do sistema de produção capitalista.

No caso específico deste estudo, a medida alternativa com função socioeducativa segue essa tradição, embora o seu caráter educativo e social expresse um incentivo ao autor do fato em conviver e participar da sociedade. A esse respeito o Caderno de Concepção (2008, p. 49) afirma:

A compreensão de que as ações socioeducativas são ao mesmo tempo "sociais" e
"educativas" nos lança ao desafio de dar sentido à junção destes termos. Portanto,
não é desejável separar o que é "sócio" daquilo que é "educativo". Trata-se de
buscar sentidos para a combinação de ambos.

A finalidade socioeducativa significa "criar situações de aprendizagens capazes de ampliar a participação e multiplicar as possibilidades de convivência" (Idem, p. 49) dos autores do fato com a sociedade.

As Bases Éticas da Ação Socioeducativa (COSTA, 2006, p.42), apontam algumas estruturas importantes que forneçam possibilidade à viabilização do ser humano:

[...] como pessoa, ajudando-o a desenvolver sua autonomia; como cidadão, contribuindo para o desenvolvimento da sua solidariedade; como futuro profissional, potencializando o desenvolvimento de suas capacidades, competências e habilidades requeridas pelo mundo do trabalho.

A natureza da função socioeducativa da medida alternativa é preparar o indivíduo para o convívio social, desenvolvendo seu potencial para não ter sua liberdade cercada. Segundo Costa (2006, p. 449), o conceito de educação que está presente na Lei de Diretrizes e Bases da Educação Nacional (Lei 9.394/96) ajuda a perceber a complexidade da função socioeducativa:

A educação abrange os processos formativos que se desenvolvem na vida familiar, na convivência humana, no trabalho, nas instituições de ensino e pesquisa, nos movimentos sociais e organizações da sociedade civil e nas manifestações culturais. (Artigo $1^{\circ}$ da LBD)

Desse conceito de educação, é possível evidenciar os vários atores e organismos que estão envolvidos no processo. Na medida alternativa não é diferente, pois para se garantir a 
função socioeducativa é preciso apoio do Estado, da família e da comunidade. O autor do fato tem a possibilidade de não responder judicialmente pelo delito que cometeu se conseguir cumprir uma medida alternativa, sendo que esta envolve atores institucionais e comunitários, para se garantir a sua educação e vida em sociedade.

Como se depreende, atualmente a função socioeducativa tem algumas características de sua origem por ainda ser uma forma de adequação do indivíduo ao sistema, mas agora com uma intencionalidade de dignificação do sujeito. O Caderno de Concepção (p. 56) afirma:

O trabalho sócio educativo contém, no mesmo movimento contraditório, a possibilidade de dominação e emancipação, ferramenta de controle e de libertação. Envolve, portanto dinâmicas pessoais e sociais de construção e reconstrução, continuidades e rupturas, características de processo de formação e desenvolvimento[...].

Portanto, a função socioeducativa da medida alternativa tem por principal objetivo incentivar o autor do fato a conviver em sociedade e responder pelo delito cometido sem que tenha, como já ressaltado, sua liberdade reprimida. O cumprimento da medida não pode se limitar a uma punição, mas deve exigir reflexões do autor do fato quanto ao delito que cometeu. A execução e o acompanhamento das medidas alternativas precisam estar integrados com o esclarecimento dos seus objetivos para garantir retorno socioeducativo para o autor do fato.

\subsection{Direitos Sociais}

É difícil conceituar a categoria dos direitos sociais tendo em vista que sua caracterização não é homogênea. Os direitos fundamentais são classificados tradicionalmente em gerações, considerando o momento de seu surgimento e reconhecimento constitucional.

Os direitos de primeira geração, composto pelos direitos civis e políticos, realçam o princípio da liberdade. Os direitos de segunda geração são os direitos econômicos, sociais e culturais, e acentuam o princípio da igualdade. Os direitos de terceira geração estão relacionados ao princípio da solidariedade e da fraternidade, e têm como exemplo o direito ao meio ambiente ecologicamente equilibrado, à paz, à autodeterminação dos povos, dentre outros. Alguns autores referem-se ainda a direitos de quarta geração, mas não há consenso quanto a existência destes. 
Os direitos sociais, como já indicado, são de segunda geração. Correspondem a direitos de participação, que são realizados por meio de políticas e serviços públicos e que exigem do Estado prestações sociais (saúde, educação, trabalho, habitação, assistência social entre outros).

"Os direitos sociais são os aqueles que têm por objeto a necessidade da promoção de igualdade substantiva, por meio do intervencionismo estatal em defesa do mais fraco". (PAULO e ALENXANDRINO, 2007, p. 97). Tais direitos são de observância obrigatória do Estado e têm por finalidade principal a melhoria das condições de vida e a da igualdade social.

Os direitos sociais estão intimamente relacionados à equidade e à justiça social. Segundo Barbalet (1989), são direitos de cidadania que complementam os direitos civis e políticos. Por isso, não se limitam ao âmbito legal, mas englobam as capacidades "[...] dos cidadãos derivadas dos recursos sociais que eles dominam e a que têm acesso". (p. 11).

Conforme Pisón (1998, p. 94), as características dos direitos sociais podem ser entendidas com base no conhecimento das causas econômicas, históricas e sociais ocorridas durante o século XIX. Os direitos sociais não se limitam às reivindicações dos movimentos dos trabalhadores, mas expressam-se também no compromisso de organizar a vida social de forma compartilhada. São características dos direitos sociais: caráter de prestação; titularidade individual, com repercussão social; remetem a um conceito de liberdade configurado a partir da igualdade (liberdade positiva); cooperação social.

Os direitos sociais, por serem direitos de prestação, demandam do Estado políticas públicas que sejam capazes de garantir sua efetivação. Segundo Pisón (1998, p. 111), somente por meio das políticas públicas, dentre as quais as sociais, é possível garantir um sistema de serviços que atendam demandas e necessidades sociais.

É nessa perspectiva que os direitos sociais se relacionam com as medidas alternativas, pois, como essa medida proporciona a continuidade de convívio social para o autor do fato, deve estar articulada com a garantia dos direitos sociais por meio das políticas públicas para que esse sujeito possa participar da sociedade de forma digna, favorecendo a função socioeducativa da própria medida.

\section{Capítulo III}

\section{Apresentação e Análise dos Resultados}


O presente capítulo destina-se à apresentação dos resultados da pesquisa empírica realizada junto ao Setor de Medidas Alternativas da Promotoria de Justiça de Brazlândia. Com a finalidade de entender a operacionalização da medida alternativa e verificar a hipótese norteadora da pesquisa, o processo de análise de dados obtidos pela investigação foi dividido em três principais etapas, de acordo com o público que forneceu informação: autores do fato; instituições; Servidora do SeMA- PJBZ e Promotora de Justiça.

\subsection{Autores do Fato}

Junto a esse segmento, a entrevista foi realizada em julho e agosto de $2008 \mathrm{com}$ dez autores do fato que finalizaram o cumprimento integral da medida alternativa. Para a aplicação da referida entrevista foi utilizado um instrumental já existente no SeMA/PJBZ, com algumas alterações para adequá-lo aos objetivos da pesquisa. Esse instrumental ainda não tinha sido aplicado por falta de recursos humanos e materiais. A entrevista foi dividida em quatro eixos principais: Perfil do Autor do Fato; Avaliação do Autor do Fato em Relação à Medida Alternativa; Avaliação do Autor do Fato em Relação à Instituição; e Avaliação do Autor do Fato em Relação à Justiça.

\subsubsection{Perfil do Autor do Fato}

A análise deste tópico permitiu visualizar informações específicas do cotidiano e da qualidade de vida dos autores do fato. Saber o perfil da população pesquisada é importante para identificar as características vivenciadas por ela.

Quanto ao sexo, três são mulheres e sete dos entrevistados são homens. A faixa etária dos entrevistados varia entre 23 e 46 anos de idade; portanto, os beneficiários das medidas alternativas à prisão fazem parte de uma população jovem. Dados sociais demonstram que o acesso e o desenvolvimento dos direitos sociais dessa população são restritos. É possível constatar esse fato ao se identificar as características de educação, trabalho e moradia.

Quanto à escolaridade, 20\% dos entrevistados têm o ensino fundamental incompleto e $40 \%$ o médio incompleto. A metade de cada percentual ainda continua estudando, enquanto 
$30 \%$ não concluíram o ensino fundamental ou médio. Em compensação, $20 \%$ já concluíram o ensino médio e $20 \%$ estão cursando o nível superior em faculdade particular. Nenhum dos entrevistados tem nível superior completo. A análise da escolaridade se faz importante, pois, em uma estrutura capitalista de produção, a educação formal tende a ser um mecanismo para a inserção no mercado de trabalho. E, mais que isso, mesmo que a educação não seja o determinante principal para a redução da criminalidade, sabe-se que ela permite ao sujeito fazer escolhas mais discernidas.

Em relação ao trabalho, 50\% dos entrevistados encontravam-se desempregados. Os demais $50 \%$ estavam trabalhando, mas, destes, apenas $20 \%$ com carteira assinada ou como servidor público. Dos 30\% restantes, 20\% declararam "fazer bico" e 10\% declararam atuar como autônomos. É importante destacar que, das cinco pessoas que estavam trabalhando, uma informou receber remuneração aquém do salário mínimo, o que, somado ao desemprego, agrava a já precária condição de vida da maioria desse segmento social.

No tocante a condição de moradia dos autores do fato, observou-se que $50 \%$ deles moram com cinco ou mais pessoas na mesma residência; $30 \%$ residem em casa cedida, $50 \%$ em casa própria e $20 \%$ em casa alugada.

A situação de baixa escolaridade, desemprego ou subemprego e condições precárias de moradia faz com que significativa parcela desse estrato populacional integre um quadro de vida e de cidadania que deixa a desejar do ponto de vida econômico e social.

\subsubsection{Avaliação do Autor do Fato em Relação à Medida Alternativa}

Em relação à medida alternativa cumprida pelo autor do fato, 50\% realizaram prestação de serviço à comunidade, $30 \%$ foram encaminhados a programas de saúde e $20 \%$

realizaram prestação pecuniária. Todos os entrevistados consideram que, na sua situação, a medida alternativa foi bem aplicada. Esse é um aspecto importante a ser considerado, pois o autor do fato é capaz de entender o motivo da medida aplicada e de relacioná-la à conduta que foi praticada. A possibilidade de reflexão sobre a medida cumprida tem um aspecto positivo para evitar a reincidência do ato infracional.

Quanto à possibilidade de o autor do fato ter obtido algum benefício socioeducativo com o cumprimento da medida, $80 \%$ afirmaram positivamente, enquanto $20 \%$ declararam indiferença quanto ao benefício ou malefício propiciado pelo cumprimento da medida 
alternativa. Portanto, um número significativo reconheceu que a medida alternativa à prisão tem caráter benéfico, demonstrando assim que o autor do fato não a restringe a uma penalidade, mas que a considera uma possibilidade de ressocialização.

Dos autores do fato entrevistados, 30\% declararam ter tido dificuldade para cumprir a medida, como, por exemplo, não conseguir conciliar o horário do cumprimento com outros afazeres e não ter dinheiro para se locomover até a instituição onde deveria prestar serviço. Os demais $70 \%$ informaram não ter tido nenhuma dificuldade para cumprir a medida, talvez porque tenha havido adequação da mesma à realidade dos autores do fato, visando diminuir as limitações para o seu cumprimento.

Em consonância com o reconhecimento majoritário da obtenção de benefício com o cumprimento da medida, nove dos dez entrevistados disseram que esse cumprimento possibilitou a prevenção de outros delitos. Apenas um discordou dessa avaliação por achar que não cometeu nada de grave para cumprir tal medida. Obter essa informação dos próprios autores do fato é significativo, pois trata da avaliação de quem foi alvo da aplicação desse instituto. Afinal, um dos objetivos dessa aplicação é a prevenção de outros delitos; e atestar na fala de quem cumpriu a medida, implica considerar que esse objetivo vem sendo atingido.

Neste tópico, foi perguntado ainda se, uma vez definida a modalidade de medida a cumprir, ela foi substituída por outra modalidade. Dos dez entrevistados apenas um teve sua medida substituída, pois o local onde participaria de um programa de saúde não possuía vaga. Mesmo assim, a medida continuou a mesma, embora ele tenha sido encaminhado para outro local. Portanto, é possível verificar que, em geral, as medidas aplicadas estão de acordo com a realidade do autor do fato.

\subsubsection{Avaliação do Autor do Fato em Relação à Instituição}

No que diz respeito à relação do autor do fato com a instituição na qual cumpriram medida alternativa, metade dos entrevistados foi encaminhada para instituição pública e a outra metade para instituição privada ou do terceiro setor. Desses entrevistados, oito declararam gostar da forma como foram tratados pelo pessoal da instituição, reclamando apenas, no caso de três, da distância do lugar e do fato de terem que trabalhar sem remuneração; já os outros dois não chegaram a freqüentar a instituição, posto que um deles prestou pecúnia em depósito bancário e, o outro, distribuiu doação por intermédio de terceiro. 
Assim, dos oito que freqüentaram a instituição, cinco afirmaram não ter enfrentado dificuldades para cumprirem a medida, o que revela a predominância da adequação da mesma à realidade social do autor do fato. $\mathrm{O}$ reconhecimento dessa adequação pode ser reforçado com a informação de nove dos entrevistados que contavam, na instituição, com algum responsável para lhes receber e lhes dar orientações. A esse respeito, apenas um não precisou de responsável institucional, pois, na própria audiência, recebeu a conta bancária da instituição para efetuar o depósito que lhe foi determinado.

Verifica-se, assim, que o fato de serem tratados com urbanidade e respeito pela instituição e de terem um responsável para lhes dar orientações é de extrema importância para que se tenha garantido o exercício da função socioeducativa da medida alternativa. Nesse caso, a função social é garantida, uma vez que incentiva o autor do fato a conviver e participar da sociedade; e a função educativa é alcançada porque, pelo menos, conscientiza o infrator de que ele também tem deveres cívicos para com a sociedade.

Por outro lado, quando o autor do fato não usufrui desse tratamento cordial e respeitoso - inclusive por desconhecer a instituição e não ter quem o oriente e o acompanhe no cumprimento da medida - ele tenderá a desconsiderar o significado desse cumprimento e a perceber a medida apenas como obrigação, deixando de reconhecer sua finalidade socioeducativa.

A possibilidade de a instituição participar construtivamente do processo socioeducativo da medida alternativa pode ser atestada na declaração dos cinco entrevistados que se sentiram úteis no ambiente e no contexto das ações institucionais, a ponto de quatro deles se sentirem motivados a se tornarem voluntários nessas ou em outras instituições. E foi o que realmente aconteceu. Um cumpridor de medida alternativa continuou prestando voluntariamente serviço de motorista para a instituição, enquanto outra, por ter formação técnica na área de enfermagem, seguiu realizando palestra sobre saúde para um grupo de idosos. Além disso, dois dos entrevistados que cumpriram medida pecuniária acharam que a instituição receptora é merecedora. Um deles acha que sua doação será bem utilizada, enquanto o outro não soube afirmar, por não ter tido contato direto com a instituição. Entretanto, os dois afirmaram que fariam novamente doações a instituições que cumprem funções socioeducativas.

Os últimos três entrevistados cumpriram a medida alternativa participando de palestra educativa e todos gostaram da terapia em grupo, que participariam novamente. 
Todos, sem exceção, confirmaram que tiveram boas experiências no cumprimento da medida na instituição, as quais se traduziram em: conscientização sobre o delito; melhoria de vida; aquisição de conhecimento; tratamento humanitário; construção de amizades e possibilidade de conseguir emprego. Isso explica porque metade dos autores do fato manteve contato com a instituição após o cumprimento da medida.

Contudo, vale salientar que esses quatro autores prestaram serviço em instituição privada ou do chamado terceiro setor. O que prestou serviço em instituição pública declarou que poderia se tornar voluntário em outra instituição, mas dependendo da situação.

Donde se infere que, a diferenciação entre instituição pública e privada ou do terceiro setor se faz necessária, uma vez que a preferência da maioria dos entrevistados coincide com a seguinte percepção desta pesquisadora, durante o seu estágio supervisionado: de que a instituição privada ou de terceiro setor tenta ser mais dos autores do fato, ao passo que as de caráter público não têm tempo ou recursos humanos para realizar essa prática.

E neste ponto da análise, tendo em vista o contingente de autores do fato que têm contato com a instituição, contam com uma pessoa de referência na mesma e revêem o delito praticado, é possível confirmar a hipótese que orientou a pesquisa. $\mathrm{O}$ cumprimento da medida alternativa tem importante função socioeducativa ao provar para o autor do delito que ele é útil socialmente. Mas, para tanto, a aplicação dessa medida tem que proporcionar o convívio social do autor do fato, não o privando de sua liberdade.

\subsubsection{Avaliação do Autor do Fato em Relação ao Sistema de Justiça}

Em todos os casos analisados, os entrevistados afirmaram que a sugestão da medida alternativa à prisão foi feita pelo Promotor de Justiça em audiência e nenhuma pelo SeMA PJBZ.

Ao realizar estágio supervisionado nesta unidade do MPDFT, foi possível verificar que realmente há dificuldades do SeMA - PJBZ em realizar o atendimento com os autores do fato antes da audiência, seja por questão de insuficiência de recursos humanos, seja por falta de tempo antes da audiência. A prática costumeira é a do autor do fato ser encaminhado após a audiência para o Setor, para que seja conscientizado sobre a medida a ser cumprida e encaminhado para a instituição. 
Porém, algumas propostas são feitas pelo SeMA - PJBZ. Na opinião desta pesquisadora, essa pratica deveria ser a ideal, pois o autor do fato em audiência chegaria mais inteirado da proposta a lhe ser apresentada e estaria mais consciente sobre as conseqüências de aceitar ou não a medida.

O SeMA - PJBZ tem uma atuação intensa com o os autores que deixam de cumprir a medida acordada, averiguando os motivos e tentando sanar os problemas que os impedem de realizar o cumprimento da medida alternativa à prisão.

Dos autores entrevistados, $60 \%$ disseram que não houve nada que os pressionassem a aceitar a homologação da medida. Mas 40\% revelaram que houve alguma pressão, como, por exemplo, "não ter direito à defesa", "não entendeu muito bem os termos utilizados", “o promotor ameaçou denunciar" e "estar diante do juiz".

Da mesma forma, 70\% dos entrevistados disseram que foram informados de que tinham a opção de aceitar ou não a medida, enquanto 30\% não ficaram sabendo dessa opção. E 60\% indicaram que foram esclarecidos sobre as conseqüências de aceitar ou não a medida, e entenderam os termos utilizados na audiência, contra os demais $40 \%$ que afirmaram o contrário (não terem sido esclarecidos sobre essas conseqüências e não entenderam os termos da audiência).

Com efeito, é preciso garantir que o autor do fato obtenha todas as informações sobre a medida alternativa à prisão, pois, do contrário, ela deixa de ter caráter de acordo e passa a ter conotação de pena, por configurar uma imposição.

Nove dos entrevistados acharam correta a atitude da Justiça em relação à aplicação da sua medida a ser cumprida; apenas um não a considerou correta, pois não teve oportunidade de falar e se defender. Desses nove, um achou que ele e a sua família deveriam ter sido mais acompanhados e outro informou que o Juiz não deixou explicar a sua situação.

Esse fato ocorre com freqüência, pois, como não há continuidade do processo, dada a possibilidade do emprego da medida alternativa, não há oportunidade de defesa. Se o autor do fato pretende se defender deve optar pela continuidade do processo e não pela medida alternativa à prisão. Mas isso também deveria ser bem esclarecido na propositura da medida.

\subsection{Instituições}


Com o objetivo de verificar a atuação das instituições que recebem os autores do fato para cumprir medida alternativa, foi aplicado questionário em uma instituição pública e em outra do terceiro setor. Neste tópico, a ênfase será maior sobre a prestação de serviço, pois é o tipo de medida alternativa em que o autor do fato passa mais tempo na instituição e recebe desta acompanhamento mais prolongado.

No ano de 2008, a instituição pública pesquisada recebeu sete autores do fato, enquanto a instituição do terceiro setor recebeu 14 autores para cumprimento da medida alternativa. Pode-se perceber, assim, que a instituição do terceiro setor recebeu o dobro de autores do fato em relação à instituição pública.

Esse fato ocorre por vários motivos; mas, acredita-se que o mais importante é o fato de que, o órgão ministerial, conhecendo a atuação e o compromisso da instituição privada, ou do terceiro setor, prefere fazer os encaminhamentos para estas instituições. Além disso, tais instituições normalmente precisam de maior ajuda da comunidade do que os órgãos públicos, que já recebem ou deveriam receber subsídio do Estado para se manterem.

Ao tratarem da importância social e educativa da medida alternativa, as instituições informaram que é importante reeducar os autores do fato, no que diz respeito aos valores pessoais e sociais, para preservar a dignidade humana do indivíduo e para reintegrá-lo à sociedade. Essa concepção das instituições demonstra que há tentativa de participarem do processo de concretização da função socioeducativa da medida alternativa.

No tocante ao papel da instituição como coadjuvante da justiça, a do terceiro setor afirmou que são responsáveis por receber e orientar o autor do fato quanto ao trabalho desenvolvido na instituição, bem como prestar qualquer tipo de esclarecimento em relação ao cumprimento da medida. A instituição pública relatou que tem função de ensinar o autor do fato a colaborar com a sociedade.

As instituições explicaram também os procedimentos adotados para realizar o acompanhamento do autor do fato. Em síntese, as duas instituições informaram que, ao receberem o autor do fato, tentam realizar uma ação condizente com suas aptidões e capacidades. Apresentam as dependências do local e as alternativas de serviços de que necessitam. Por fim, avaliam o prestador de serviço (autor do fato) com base nos seguintes quesitos: comportamento, assiduidade, responsabilidade, dedicação, entrosamento com as pessoas, dentre outras. 
As instituições pontuaram alguns principais benefícios que a medida alternativa proporciona para o autor do fato: construção de auto-estima, disciplina, respeito à sociedade, sensação de serem úteis e de poderem pagar uma dívida para a justiça.

Quanto às dificuldades que enfrentam, ao acompanhar o cumprimento da medida alternativa, a instituição pública informou que muitos autores desejam prestar serviços nos finais de semana e que ela não funciona neste período.

A instituição do terceiro setor informou que alguns prestadores de serviços se sentem desmotivados por estarem cumprindo uma obrigação perante a justiça e acabam se desinteressando do trabalho realizado. $\mathrm{O}$ entrosamento com as outras pessoas também foi uma dificuldade relatada por esta instituição. Foi informado, ainda, que esse fato ocorre porque o próprio prestador de serviço tem preconceito em relação a sua situação.

As duas instituições informaram que deveria existir um profissional de psicologia para acompanhar o prestador de serviço mais de perto com a finalidade de contribuir com a socioeducação do mesmo.

A instituição do terceiro setor sugeriu, ao final da entrevista, que algum representante da justiça acompanhasse o autor do fato na instituição. Acrescentou que é necessário haver visitas periódicas dos órgãos que encaminham os autores do fato. Entende-se, portanto, que esse seja um aspecto importante para o desenvolvimento e efetividade da medida alternativa, pois instruir a instituição para receber os autores do fato é de extrema necessidade.

\subsection{Servidora do SeMA - PJBZ e Promotora de Justiça}

$\mathrm{Na}$ tentativa de averiguar o cumprimento da função socioeducativa da medida alternativa, entendeu-se ser importante analisar a percepção de quem propõe e acompanha a referida medida. Representando o Ministério Público, uma Promotora de Justiça e uma servidora do SeMA-PJBZ participaram dessa pesquisa fornecendo informações.

Ao tratar da importância social e educativa da medida alternativa à prisão, ficou evidenciado que o MPDFT busca garantir a efetivação da função socioeducativa da medida. Além da possibilidade de o autor do fato não ter sua liberdade cerceada, ele pode ter consciência do ato que cometeu, participando mais da comunidade ao cumprir a medida.

Sobre esse tema afirmou a servidora do SeMA- PJBZ: “A medida alternativa dá mais condições da pessoa se auto-avaliar, de se ver parte da comunidade e de planejar o seu futuro 
positivamente"; e a Promotora de Justiça assinalou: "O cumprimento da medida, na minha visão, tem duplo alcance. Ao passo em que visa a responsabilização do acusado, busca inserilo dentro da realidade social".

Foram citados, por ambas as entrevistadas, vários benefícios que os autores do fato têm ao cumprir a medida alternativa, quais sejam: conhecer a realidade da comunidade, ajudar os semelhantes com serviços voluntários, refletir sobre a conduta inadequada que cometeu, dentre outros.

A servidora do SeMA-PJBZ referiu-se, ainda, às contribuições que a própria sociedade tem no cumprimento da medida alternativa. Para ela, a sociedade tem um retorno positivo da Justiça, pois o autor do fato que cometeu algum delito, deve contribuir com a comunidade, prestando doação ou serviços nas instituições para onde são encaminhados.

Ao dizerem o que o Ministério Público tem feito para garantir a função socioeducativa da medida alternativa ao autor do fato, tanto a Promotora de Justiça quanto a Servidora do SeMA ressaltaram a existência da Central de Medidas Alternativas, pois essa unidade busca adequar a medida ao perfil sócio-econômico do autor do fato; realizar visitas às instituições parceiras, a fim de orientá-las quanto ao recebimento e acompanhamento do autor do fato; garantir conhecimento dos direitos pelo autor do fato; e encaminhar o autor do fato à rede social da localidade para atender demandas e necessidades sociais nas respectivas instituições.

Por ter realizado o estágio curricular no SeMA/PJBZ, esta pesquisadora pode citar exemplos importantes de encaminhamentos à rede social: ao CRAS, para recebimento de benefícios; ao Hospital Regional, para realizar consultas; à diretoria da Regional de Ensino, para fornecer reforço escolar aos filhos dos autores, dentre várias outras instituições da região, que podem dar suporte não só ao autor do fato, mas também a sua família.

Estas informações comprovam a hipótese de trabalho levantada para nortear a pesquisa, pois, realmente, a execução da medida alternativa tem importante função socioeducativa pelo fato de proporcionar ao autor do delito a possibilidade de não privá-lo do convívio social e de torná-lo útil à sociedade no momento em que está cumprindo a medida.

É importante destacar também as sugestões e reclamações quanto ao instituto da medida alternativa que foram levantadas pelas entrevistadas: melhorar o relacionamento da Justiça com as instituições parceiras; garantir atendimento psicossocial ao autor do fato; e melhorar a fiscalização da prestação de serviços a fim de verificar o desempenho e os resultados obtidos pelo referido autor. 


\section{Considerações Finais}

O presente Trabalho de Conclusão de Curso procurou explicitar o significado e a contribuição socioeducativa da medida alternativa à prisão. Foram utilizados aportes teóricos e pesquisa empírica para realizar estudo do tema e do objeto.

Tendo por base os resultados da pesquisa é possível pontuar as principais contribuições da utilização do instituto da medida alternativa à prisão.

Com relação aos autores do fato, a pesquisa realizada evidenciou que a função socioeducativa da medida alternativa está sendo garantida, pois, além de não privar a liberdade do indivíduo, permite que este tenha uma participação efetiva na sociedade ao realizar a prestação pecuniária ou a prestação de serviço.

Outro aspecto a ser destacado é a possibilidade que o autor do fato tem de refletir sobre o ocorrido no processo, tendo em vista que, numa análise abrangente, essa possibilidade contribui para prevenir a reincidência do fato cometido. Isso confirma a hipótese levantada no no processo investigativo visto que ela está de acordo com os resultados da pesquisa.

A falta de diálogo entre os membros da Justiça que aplicam a medida alternativa e as instituições que acompanham os autores do fato foi um problema pontuado por esses dois atores. Atualmente, o SeMA-PJBZ está com recursos humanos mais disponíveis que na época da pesquisa. Com esse avanço e melhorias de condições materiais, é possível pensar maneiras de viabilizar esse dialogo em prol da contribuição socioeducativa da medida alternativa à prisão.

Apesar de não ter sido foco deste estudo, uma sugestão se faz necessária para melhorar a realidade do instituto da medida alternativa, qual seja: a inserção do profissional de Serviço Social para atuar na área, uma vez que este profissional possui habilidade e competências que o capacitam a ler e diagnosticar a realidade social, intervir nessa realidade, estabelecer relações inter-institucionais, realizar encaminhamentos para a rede social, dentre outras atribuições previstas na Lei de Regulamentação da profissão (Lei 8.662 de 1993) e no Código de Ética Profissional do Assistente Social.

O que mais impressiona no instituto da medida alternativa é não só o seu contraponto às mazelas da pena de prisão, mas o envolvimento, no seu processo, da comunidade, do autor do fato e do Estado. A exigência de um trabalho integrado responsabiliza todos esses atores para atuarem na sua realização. 
Por ser um instituto novo na área penal, a medida alternativa ainda possui algumas falhas, principalmente no que diz respeito à impossibilidade de defesa do autor do fato. Mas, pensando nas contribuições socioeducativas que propicia, a medida alternativa é um grande avanço em relação aos tipos de penas que vêm sendo utilizados ao longo da história do controle do Estado sobre autores de fatos delituosos. 


\section{Referências Bibliográficas}

BARBALET, J. M. A Cidadania. Lisboa: Editorial Estampa, 1989.

BARROSO, Anamaria Prates. Coleção Resumo: Direito Penal. Brasília: Instituto Processus, 2003.

BECCARIA, Cesare Bonesana, Marchesi di, 1738-1794; GUIMARÃES, Deocleciano Torrieri - (Trad.). Dos delitos e das penas. São Paulo: Rideel, 2003.

BITENCOURT, Cezar Roberto. Falência da pena de prisão: Causas e alternativas. 3. ed. São Paulo: Saraiva, 2004. 396 p.

BRASIL. Decreto-Lei no 2.848, de 7 de dezembro de 1940. Código Penal Brasileiro.

BRASIL. Lei 8.069, de 13 de julho de 1990. Dispõe sobre o Estatuto da Criança e do Adolescente e dá outras providências.

BRASIL. Lei 9.099, de 26 de setembro de 1995. Dispõe sobre os Juizados Especiais Cíveis e Criminais e dá outras providências.

BRASIL. Lei 9.394, de 20 de dezembro de 1996. Estabelece as diretrizes e bases da educação nacional.

BRASIL. Lei 9.714, de 25 de novembro 1998. Altera dispositivos do Decreto-Lei $\mathrm{n}^{\mathrm{o}} 2.848$, de 7 de dezembro de 1940 - Código Penal.

Caderno de Concepção: Juventudes e Adolescência, Serviço Socioeducativo de Proteção Social Básica, Sistema Único de Assistência Social. Brasília: Secretaria Nacional de Assistência Social, $2008 . \quad$ Disponível em: http://www.integribrasil.com.br/Integri.Web/arquivos/1211373858.pdf. Acesso em: 20 de março de 2009. 
CAPEZ, Fernando. Curso de Direito Penal: volume 1 (art. $1^{\circ}$ a 120 ). 8. ed. ver. e atual. de acordo com as Leis n. 10.741/2003 (Estatuto do Idoso), 10.763/2003 e 10.886/2004. São Paulo: Savaira, 2005.

Cartilha de Orientação sobre Medidas Alternativas. MPDFT, 2006.

COSTA, Antônio Carlos Gomes. As Bases Éticas da Ação Socioeducativa: referenciais normativos e princípios norteadores. Brasília: Secretaria Especial dos Direitos Humanos, 2006.

COSTA, Antônio Carlos Gomes. Natureza e Essência da Ação Socioeducativa. In: ILANUD; ABMP; SEDH; UNFPA (orgs.). Justiça, Adolescente e Ato Infracional: socioeducação e responsabilização. São Paulo: ILANUD, 2006.

DOTTI, René Ariel. Bases alternativas para o sistema de penas. 2. ed. São Paulo: Editora Revista dos Tribunais, 1998.

GARCIA, Ismar Estulano. Procedimento nas Infrações de Menor Potencial Ofensivo. Goiânia: AB, 2005.

JEREMY Bentham. In: Wikipédia: a enciclopédia livre. Disponível em: $<$ http://pt.wikipedia.org/wiki/Jeremy_Bentham> Acesso em: 18 de dezembro de 2008.

LAKATOS, Eva Maria. Fundamentos de Metodologia Científica. Marina de Andrade Marconi, Eva Maria Lakatos. 6. ed. São Paulo: Atlas, 2007.

LINS e SILVA, Evandro. O Salão dos Passos Perdidos: depoimento ao CPDO. Rio de Janeiro. Editora Fronteira, 1997.

MIRABETE, Julio Fabbrini. Manual de direito penal, volume I: parte geral, arts. $1^{\circ}$ a 120 do CP / Julio Fabbrini Mirabete, Renato N. Fabbrini. - 24. ed. rev. e atual. até 31 de dezembro de 2006. - São Paulo: Atlas, 2007.

NUCCI, Guilherme de Souza. Manual de direito penal: parte geral : parte especial. 4. ed. Rev. E atual e ampl. 2. tir. - São Paulo: Editora Revista dos Tribunais, 2008. 
PAULO, Vicente. ALEXANDRINO, Marcelo. Direito Constitucional Descomplicado. Rio de Janeiro: Impetus, 2007.

PEREIRA, Potyara A. P. Controle Democrático como garantia de direitos da pessoa idosa. Brasília: Secretaria Especial de Direitos Humanos, Subsecretaria de Promoção e Defesa dos Direitos Humanos. 2007.

PEREIRA, Potyara A. P. Política Social: temas \& questões. São Paulo: Cortez, 2008.

PISÓN, José Martinez. Politicas de Bienestar: um estudio sobre los derechos sociales. Madrid: Teenos, 1998.

Regras de Tóquio: comentário às regras mínimas das Nações Unidas sobre medida nãoprivativa de liberdade / tradução de Damásio E. de Jesus; prefácio de Íris Rezende. Brasília: Ministério da Justiça, 1998.

Retrato das Penas e Medidas Alternativas 2006: Ceilândia, Taguatinga, Samambaia, Gama, Brazlândia e Guará - dados referentes ao ano de 2005. MPDFT, 2006.

SÁNCHEZ, Jesus Maria Silva. A Expansão do Direito Penal: Aspectos da Política Criminal nas sociedades pós industriais. Tradução de Luiz Otavio de Oliveira Rocha. São Paulo: Revista dos Tribunais, 2002.

TOURINHO NETO, Fernando da Costa; FIGUEIRA JÚNIOR, Joel Dias. Juizados Especiais Cíveis e Criminais: Comentários à Lei 10.259, de 10.07.2001. São Paulo: Revista dos Tribunais, 2002. 


\section{Apêndice}

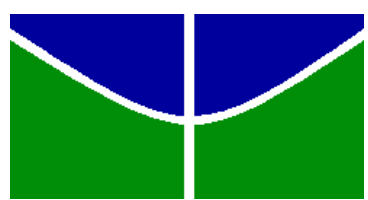

\section{UNIVERSIDADE DE BRASÍLIA - UnB \\ INSTITUTO DE CIÊNCIAS HUMANAS - IH \\ DEPARTAMENTO DE SERVIÇO SOCIAL - SER}

Prezado(a) Senhor(a),

Na qualidade de aluna do Curso de Serviço Social da Universidade de Brasília, e pesquisadora do tema "Significado e Alcance Sócio-educativo das Medidas Alternativas à Prisão”, gostaria de contar com a sua valiosa colaboração no sentido de fornecer informações necessárias à elaboração de meu Trabalho de Conclusão de Curso (TCC). A importância dessas informações, a serem coletadas por meio do questionário anexo, reside no fato de que, com elas, poderei ampliar meu conhecimento sobre o tema e verificar, com mais precisão, minha hipótese de trabalho - que poderá ser objeto de novos e mais avançados estudos.

Asseguro-lhe o sigilo de sua participação cuidando para que as informações prestadas não sejam identificadas. A qualquer momento o(a) senhor(a) poderá desistir de participar da pesquisa e retirar o seu consentimento, sem risco de prejuízo na sua relação com esta estudante ou com a Universidade.

Agradecendo antecipadamente a sua colaboração, coloco-me à disposição para esclarecimentos que se fizerem necessários.

Estudante: Izabel Fernandes Gomes

Telefone: 3354-6573 ou 84126505

E-mail: izabelcomz@hotmail.com

Orientadora: Prof ${ }^{a}$ Dr $^{a}$ Potyara A. P. Pereira 


\section{QUESTIONÁRIO PARA COLETA DE INFORMAÇÕES SOBRE MEDIDA ALTERNATIVA À PRISÃO - MINISTÉRIO PÚBLICO}

1. A seu ver, qual a importância social e educativa da medida alternativa à prisão?

2. Acha que o cumprimento da medida alternativa traz algum benefício para o autor do fato e para a sociedade? Por quê?

3. $\mathrm{O}$ (a) senhor(a) tem sugestões ou reclamações quanto ao instituto da medida alternativa? Quais?

4. O que o Ministério Público tem feito para garantir a função socioeducativa da medida alternativa para o autor do fato?

\section{QUESTIONÁRIO PARA COLETA DE INFORMAÇÕES SOBRE MEDIDA ALTERNATIVA À PRISÃO NAS INSTITUIÇÕES QUE ACOLHEM AUTORES DE FATOS DELITUOSOS}

1. Quantos autores de fatos delituosos esta instituição recebeu no ano de 2008 para cumprir medida alternativa?

2. A seu ver, qual a importância social e educativa da medida alternativa à prisão?

3. Qual o papel da instituição que recebe o autor do fato, como coadjuvante da justiça?

4. Que procedimentos a sua instituição adota para acompanhar o autor do fato? Cite todas as fases.

5. $\mathrm{O}$ (a) Senhor(a) acha que o cumprimento da medida alternativa traz algum benefício para o autor do fato e para a sociedade? Por quê?

6. A sua instituição já encontrou alguma dificuldade no acompanhamento de algum autor do fato? Qual? Por quê?

7. A seu ver, o que, na sua instituição, deveria existir para que ela possa melhor contribuir com a socioeducação do autor do fato?

8. O(a) Senhor(a) tem sugestões ou reclamações quanto ao acompanhamento de autores de fatos que cumprem medida alternativa em sua instituição? Quais?

9. Sua instituição tem recebido apoio do Ministério Público ou do Tribunal de Justiça no acompanhamento de autores de fatos? 


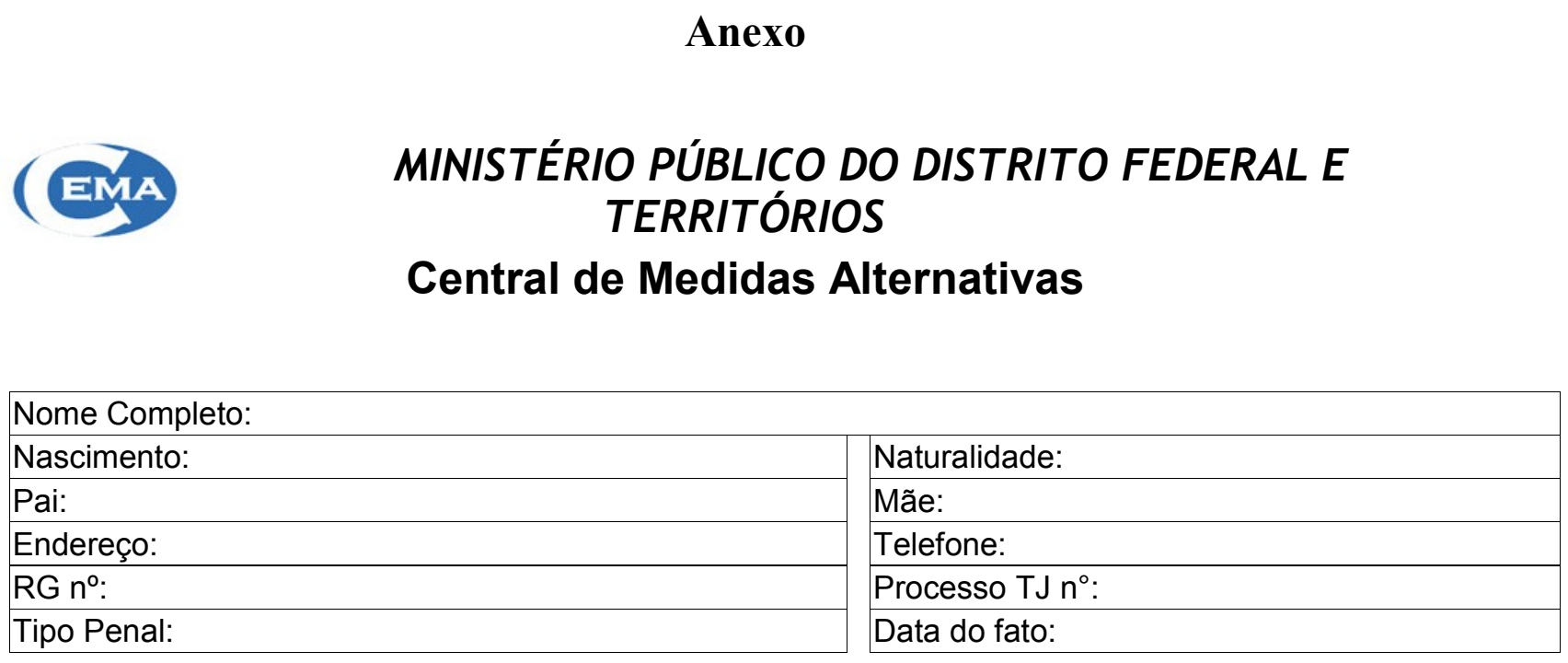

\section{RELATÓRIO FINAL DO AUTOR DO FATO}

N. ${ }^{\circ}$ do RFAF:

Data:

Perfil do Autor do Fato:

1) Cursou ou está cursando que série ?

2) Atualmente está trabalhando ?

Cargo:

Sim ( )

Não ( )

Carteira Assinada ( )

Autônomo ( )

Renda mensal aproximada:

3) Quais são suas expectativas para o futuro ?

4) Com quem mora?

5) Estado Civil:

6) Tem filhos ?

$\operatorname{Sim}(\quad)$

Não ( )

Quantos?

7) Paga pensão alimentícia ?

Valor:

$\operatorname{Sim}(\quad)$

Não ( ) 
8) Mora em casa:

( ) Própria

( ) Alugada - Valor:

( ) Outros - Especificar:

\section{Avaliação do Autor do Fato em relação à medida alternativa}

Medida cumprida:

9) O que você entende por medida alternativa?

10) Você considera que a medida alternativa foi bem aplicada na sua situação ?

$\operatorname{Sim}(\quad) \quad$ Não ( )

Por quê?

11) Você identifica algum benefício após o cumprimento da medida?

$\operatorname{Sim}($ ) Não ( )

Quais (pessoal, em relação ao delito, em relação à família, em relação ao trabalho, ...) ?

12) Houve dificuldade no cumprimento da medida?

$\operatorname{Sim}(\quad)$

Não ( )

Quais (passagem, horário, ...) ?

13) Acha que o cumprimento da medida alternativa possibilita a prevenção de outros delitos?

14) Houve substituição da medida ?

Motivo:

$\operatorname{Sim}()$

Não ( )

\section{Avaliação do Autor do Fato em relação à instituição}

Nome da Instituição:

15) O que você achou bom na instituição ?

16) O que você achou ruim na instituição ?

17) Havia algum responsável na instituição para Ihe receber e dar orientações ?

Quem?

$\operatorname{Sim}($ ) Não ( )

18) No caso de prestação de serviços: você considera que foi bem aproveitado pela instituição ?

Por quê?

$\operatorname{Sim}(\quad) \quad$ Não ( )


19) No caso de prestaçao pecuniária: você considera que sua doação será bem utilizada?
$\operatorname{Sim}(\quad)$
Não ( )

Você considera que a instituição é merecedora da doação ?

$\operatorname{sim}(\quad)$

Não ( )

20) Você doaria ou prestaria serviços novamente e se tornaria voluntário NESTA instituição ?
$\operatorname{Sim}(\quad)$
Não ( )

21) Você doaria ou prestaria serviços novamente e se tornaria voluntário EM OUTRA instituição?

$\operatorname{Sim}(\quad)$

Não ( )

22) O cumprimento da medida na instituição foi uma experiência:

Por quê ?

$$
\text { Positiva ( ) Negativa ( ) }
$$

23) Você considera que foi visto e tratado na instituição de forma:

Por quê?

$$
\text { Positiva ( ) Negativa ( ) }
$$

24 ) Após o cumprimento da medida você manteve contato com a instituição ?

$$
\operatorname{Sim}() \quad N a ̃ o(1)
$$

25) Você tem sugestões ou reclamações em relação à instituição ?

Quais?

$\operatorname{Sim}()$

Não ( )

\section{Avaliação do Autor do Fato em relação à Justiça}

26) A sugestão da medida foi feita:

( ) pelo Promotor de Justiça, em audiência

( ) pela CEMA

( ) outros - Especificar:

27) Houve algo que o pressionasse na homologação da medida ?

O quê?

$\operatorname{Sim}(\quad)$

Não ( )

28) Você sabia que tinha a opção de aceitar ou não a medida alternativa ?

$\operatorname{Sim}($ ) Não ( )

29) Você foi esclarecido sobre as conseqüências de aceitar ou não a medida alternativa?

$\operatorname{Sim}(\quad) \quad N a ̃ o(\quad)$

30) Você entendeu os termos que foram colocados na audiência?

$\operatorname{Sim}(\quad)$

Não ( ) 
31) Você achou correta a atitude da Justiça em relação à aplicação de sua medida ? $\operatorname{Sim}($

Não ( )

Por quê?

32) Você considera o tratamento da Justiça:

Por quê ?

Positivo ( ) Negativo ( )

33) Você tem sugestões ou reclamações em relação à Justiça ?

Quais?

$\operatorname{Sim}(\quad) \quad$ Não ( 